\title{
Molecular targeted therapies in adrenal, pituitary and parathyroid malignancies
}

\author{
Anna Angelousi', Georgios K Dimitriadis², Georgios Zografos3, Svenja Nölting4, \\ Gregory Kaltsas1,2,5 and Ashley Grossman ${ }^{5}$
}

1Department of Pathophysiology, Sector of Endocrinology, National \& Kapodistrian University of Athens, Athens, Greece

2Division of Translational and Experimental Medicine, University of Warwick Medical School, Clinical Sciences Research Laboratories, Coventry, UK

3Third Department of Surgery, Athens General Hospital "Georgios Gennimatas", Athens, Greece ${ }^{4}$ Department of Internal Medicine II, Campus Grosshadern, University-Hospital, Ludwig-MaximiliansUniversity of Munich, Munich, Germany

${ }^{5}$ Department of Endocrinology, Oxford Centre for Diabetes, Endocrinology and Metabolism, Churchill Hospital, University of Oxford, Oxford, UK

Correspondence should be addressed to A Angelousi Email a.angelousi@gmail.com

\begin{abstract}
Tumourigenesis is a relatively common event in endocrine tissues. Currently, specific guidelines have been developed for common malignant endocrine tumours, which also incorporate advances in molecular targeted therapies (MTT), as in thyroid cancer and in gastrointestinal neuroendocrine malignancies. However, there is little information regarding the role and efficacy of MTT in the relatively rare malignant endocrine tumours mainly involving the adrenal medulla, adrenal cortex, pituitary, and parathyroid glands. Due to the rarity of these tumours and the lack of prospective studies, current guidelines are mostly based on retrospective data derived from surgical, locoregional and ablative therapies, and studies with systemic chemotherapy. In addition, in many of these malignancies the prognosis remains poor with individual patients responding differently to currently available treatments, necessitating the development of new personalised therapeutic strategies. Recently, major advances in the molecular understanding of endocrine tumours based on genomic, epigenomic, and transcriptome analysis have emerged, resulting in new insights into their pathogenesis and molecular pathology. This in turn has led to the use of novel MTTs in increasing numbers of patients. In this review, we aim to present currently existing and evolving data using MTT in the treatment of adrenal, pituitary and malignant parathyroid tumours, and explore the current utility and effectiveness of such therapies and their future evolution.
\end{abstract}

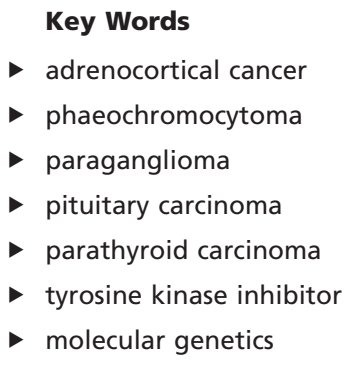

Endocrine-Related Cancer (2017) 24, R239-R259

\section{Introduction}

There are numerous specific guidelines developed for the relatively common malignant endocrine tumours such as thyroid cancer and gastrointestinal neuroendocrine tumours (NETs) (Haugen et al. 2016, Pavel et al. 2016), but there is a paucity for other less common endocrine carcinomas involving the parathyroids, adrenals, and the pituitary gland. Parathyroid tumours have an incidence of 80 and 36 per 100,000 population in women and

Published by Bioscientifica Ltd 
men aged 50-59 years, respectively (Yeh et al. 2013), and occasionally can be multiple. Similarly, pituitary and adrenocortical tumours have a prevalence of $16.7 \%$ (range 14.4-22.5) and 4\% (range 1.0-8.7), respectively, the latter increasing with age (Ezzat et al. 2004, Zeiger et al. 2009, Fassnacht et al. 2016). Tumours derived from the adrenal medulla occur less commonly with a prevalence of 1/2500-6500, (Kantorovich et al. 2015), although autopsy series have revealed a prevalence of $0.05-0.1 \%$ (McNeil et al. 2000, Lenders et al. 2014). Adrenocortical carcinomas (ACCs) account for up to 11\% (range 1.2$12 \%$ ) of adrenocortical tumours, whereas up to $25 \%$ of phaeochromocytomas (PCs) may become malignant (Ayala-Ramirez et al. 2011, Fassnacht et al. 2016). Approximately, $0.2 \%$ of pituitary tumours can develop cranial and extra-cranial metastases (Kaltsas et al. 2005a, Heaney et al. 2011), whereas the incidence of parathyroid carcinomas is estimated at less than $1 \%$ in patients with primary hyperparathyroidism, although studies from Japan have reported a higher incidence of 5\% (Hamill et al. 2002, Givi \& Shah 2010, Mohebati et al. 2012).

Currently, the optimal management of malignant tumours originating from the pituitary, parathyroid, and adrenal glands is not well defined. The standard treatments for these tumours include surgery, locoregional and ablative therapies, administration of somatostatin analogues (SSAs), radionuclides and systemic chemotherapy, albeit with limited efficacy, necessitating the development of more effective treatments.

Recent advances in our understanding of the genetic pathways implicated in the pathogenesis of these tumours are expected to lead to a more personalised approach directed at the specific molecular aberrations. The most common pathways involved in endocrine tumour pathogenesis are the phosphatidylinositol-4, 5-bisphosphate 3-kinase (PI3K)/AKT/mammalian target of rapamycin (mTOR) and the RAS-mitogen-activated protein kinase (MAPK) cascades, both downstream of growth factor receptors such as the insulin-like growth factor-1 receptor (IGF1-R) (Nölting \& Grossman 2012, Ribeiro et al. 2012, Favier et al. 2015) (Fig. 1A and B). Angiogenesis stimulation also seems to play a major role in tumourigenesis, with vascular epithelial growth factor receptors (VEGF-Rs), platelet-derived growth factor receptor (PDGF-Rs), endothelial growth factor receptors (EGF-Rs), and tyrosine kinase inhibitors (TKIs) being the most studied targeted pathways in preclinical and clinical studies (Hay \& Sonenberg 2004, O'Reilly et al. 2006, De Martino et al. 2014).
In this review, we aim to present available novel and evolving in vitro and in vivo data on molecular pathways involved in the malignant transformation of adrenal malignancies, pituitary and parathyroid carcinomas, as well as evidence from current clinical applications of molecular targeted treatment (MTT).

\section{Phaeochromocytomas and paragangliomas}

\section{Introduction}

Phaeochromocytomas (PCs) arise from the adrenal chromaffin cells, whereas paragangliomas (PGLs) are derived from the extra-adrenal sympathetic chromaffin (sympathetic PGLs) and/or parasympathetic tissue (non-chromaffin PGLs) of the head and neck (HNPGLs) (Lenders et al. 2005). In 2004, the WHO defined malignant PCs/PGLs in the presence of metastatic disease without considering locally recurrent or invasive tumours (AyalaRamirez et al. 2011). Based on this classification, PCs exhibit a 15-20\% 10-year probability of recurrence with a $20 \%$ malignancy rate (Ayala-Ramirez et al. 2011). Overall, metastatic PCs/PGLs are rare with an incidence of less than $1 / 1,000,000$ population per year, with sympathetic PGLs being more common than PCs ( $60 \%$ vs $25 \%$, respectively). However, no current treatment for malignant PCs/PGLs has been shown to be particularly effective (Lenders et al. 2014). Better understanding of the molecular pathways for the PCs/PGLs pathogenesis has led to the development of potential new therapeutic agents. Data from clinical trials using MTT are summarised in Table 1.

Transcriptomic studies have identified two main activated molecular pathways leading to the development of these tumours: the hypoxic (cluster-1 genes), mainly involving the succinate dehydrogenase $(\mathrm{SDH} x)$ and the Von Hippel-Lindau (VHL) genes, and the mTOR (cluster-2 genes) pathways, mainly involving rearranged during transfection (RET) and neurofibromin 1(NF1) genes (Dahia et al. 2005, 2014, Favier et al. 2015). DNA-methylation profiling studies have uncovered a hyper-methylator phenotype in the SDHx gene-related tumours (comprising $S D H A / B / C / D$ and SDHAF2 genes) and showed that succinate acts as an onco-metabolite, inhibiting 2-oxoglutarate-dependent dioxygenases. 'Omics' data have also identified new therapeutic targets (Favier et al. 2015).

\section{Current treatment based on clinical trials}

Current guidelines suggest that the optimal initial treatment for metastatic PCs/PGLs should be surgical,

Published by Bioscientifica Ltd 
A

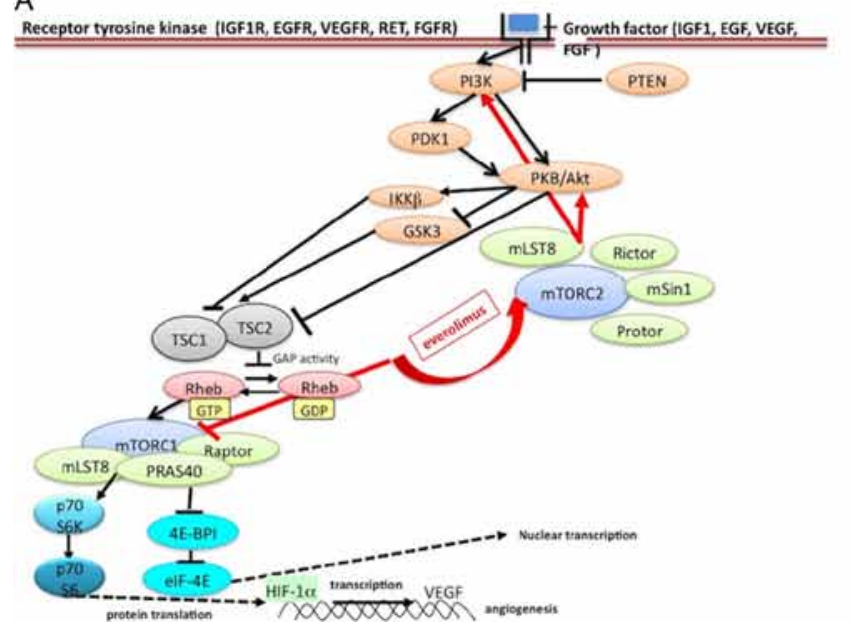

B

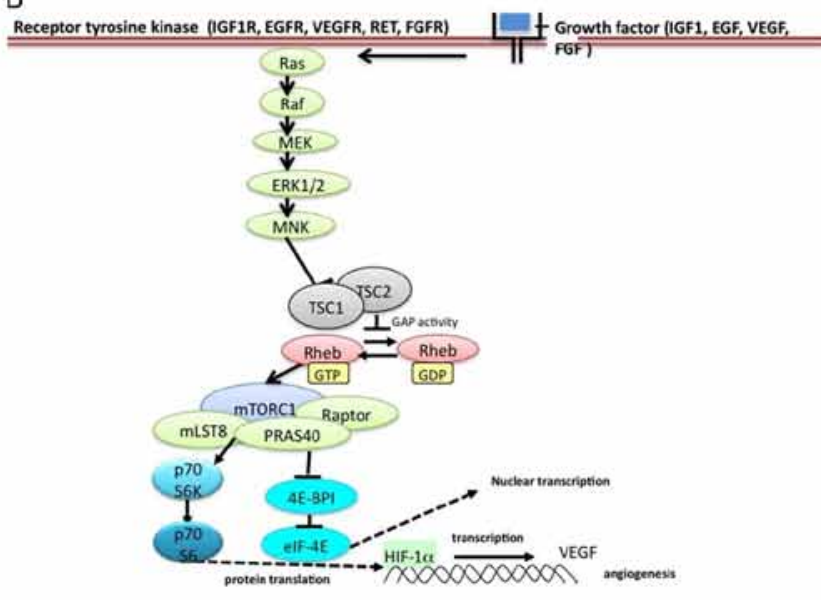

Figure 1

(A) PI3K/Akt/mTOR pathway: The IGF1R activates tyrosine kinase receptor through the lipid kinase PI3K/Akt pathway. PI3K activation phosphorylates and activates Akt that inhibits TSC1/TSC2 suppressor complex, which in turn activates mTORC1. PTEN is a major negative regulator of A activation. Aktmediated phosphorylation of TSC1-TSC2 leads to the activation of the Rheb-a GTPase- that activates the mTORC1. The mTOR signalling pathway serves as the central regulator of cell metabolism and proliferation. $\mathrm{mLST} 8$ is a common subunit of both mTORC1 and mTORC2, and is necessary for activation of the mTOR kinase. PRAS40 is another component and substrate of mTORC1 whose phosphorylation by mTORC1 results in its dissociation from mTORC1 inhibiting mTORC1 activity. Growth-factor-stimulated PI3K signalling also activates mTORC2, which regulates actin cytoskeletal organisation, ion transport and growth. mTORC2 consists of the mTOR catalytic subunit and at least five accessory proteins. Rictor, mSin1, and Protor are unique subunits of mTORC2. Everolimus is known to inhibit mTORC1, but increase Akt signalling. (B) MAPK pathway: Signalling via the RAS-RAF-MEK-ERK cascade leads to phosphorylation of many substrates that can have multiple cellular effects. RAS-GTP activates RAF that activates the mitogen-activated protein kinase kinase 1/2 (MEK1/2). MEK1 and MEK2 then phosphorylate ERK1 and ERK2. ERK also feeds back to negatively regulate the pathway. ERK kinase can phosphorylate transcription factors that control the cell cycle including TSC1/2 mediated by the p90RSK which in turn activates mTORC1. Akt, protein kinase $\mathrm{B}$; elF-4E, elongation initiation factor $4 \mathrm{E}$; $4 \mathrm{E}-\mathrm{BPI}$, eukaryotic initiation factor $4 \mathrm{E}$-binding protein 1; ERK/MAPK, extracellular-signal-regulated kinase/mitogen activated protein kinase; GSK3, glycogen synthase kinase 3; IGF1R, insulin-like growth factor 1 receptor; IKK, IR kinase; MAPK, Mitogenactivated protein kinase; MEK, mitogen-activated protein kinase kinase; mLST8, mammalian lethal with SEC13 protein 8; MNK, mitogen protein kinase; mTORC, mammalian target of rapamycin complex; PI3K/AKT, phosphatidylinositol 3-kinase/AKT; PDK, 3-phosphoinositide-dependent protein kinase; PTEN, phosphatase and tensin homologue; PRAS40, praproline-rich Akt substrate of $40 \mathrm{kDa}$; Rheb, Ras homologue enriched in brain; P70 S6, Ribosomal protein 56 kinase beta-1; TSC1/2, tunerous sclerosis complex; HIF-1a, hypoxia-induced factor 1a; VEGF, vascular growth factor.

including total resection of the tumour, locoregional lymph nodes and distant metastases (Zografos et al. 2009, Lenders et al. 2014). For unresectable disease, combination chemotherapy with cyclophosphamide, vincristine and dacarbazine (CVD) has been associated with short-term symptomatic and tumour responses of 33-65\% (Averbuch et al. 1988, Ayala-Ramirez et al. 2012b). A recent meta-analysis showed that CVD achieved a $37 \%$ tumoural and a $40 \%$ hormonal response, but only $4 \%$ of patients obtained complete remission (Niemeijer et al. 2014).

\section{Molecular targeted treatment for PCs/PGLs}

mTOR inhibitors PCs/PGLs exhibit a significant overexpression of key mTOR complex (mTORC) signalling mediators (Nölting \& Grossman 2012, Zhang et al. 2015) (Fig. 1A and B). Everolimus, a compound inhibiting mTOR and thus the PI3K/Akt/mTOR pathway, has been shown in vitro to inhibit the proliferation of human neuroblastoma cells, which are closely related to
PCs/PGLs cluster-2-related tumours (Kiessling et al. 2016). Everolimus has previously been evaluated in malignant PCs but only in small series (Semenza 2007, Druce et al. 2009, Nölting et al. 2012). In another study, all patients treated with everolimus experienced disease progression (Druce et al. 2009). This was attributed to the selective inhibition of HIF-1 without any effect on HIF2, or to the compensatory activation of the RAS/RAF/ERK pathway (Semenza 2007, Druce et al. 2009, Nölting et al. 2012). In a subsequent phase II study using everolimus as monotherapy, five of seven patients with metastatic PCs/PGLs achieved stable disease but with a progressionfree survival (PFS) of only 3.8 months (95\% CI: 0.5-7.0); four patients demonstrated tumour shrinkage (Oh et al. 2012). However, recent experimental studies with AZD8055, an ATP-competitive dual mTORC1/2 inhibitor, in metastatic mouse PC cell lines and in human primary cell models of patients with PCs/PGLs, showed a significant decrease in tumour load with a 50\% reduction in the number of malignant cells (Giubellino et al. 2013a). A recent in vivo study in mice xenografts confirmed these

Published by Bioscientifica Ltd. 
Table 1 Molecular-targeted agents used in different protocols of clinical trials completed or ongoing in patients with phaeochromocytomas (PCs) and paragangliomas (PGLs).

\begin{tabular}{|c|c|}
\hline $\begin{array}{l}\text { Protocol IDs in } \\
\text { ClinicalTrials. } \\
\text { gov/Reference }\end{array}$ & $\begin{array}{l}\text { Tested drug in the Tested } \\
\text { drug in the trial arm }\end{array}$ \\
\hline $\begin{array}{l}\text { Kulke et al. } \\
2006\end{array}$ & $\begin{array}{l}\text { Thalidomide (VEGF-R, } \\
\text { bFGF inhibitor) and } \\
\text { Temozolomide } \\
\text { (Alkylating } \\
\text { chemotherapy) }\end{array}$ \\
\hline $\begin{array}{l}\text { NCT00466856, } \\
\text { USA, } 2007\end{array}$ & $\begin{array}{l}\text { Yttrium (Y) } 90 \\
\text { octreotide acetate }\end{array}$ \\
\hline $\begin{array}{l}\text { NCT00655655, } \\
\text { USA, } 2008\end{array}$ & $\begin{array}{l}\text { Everolimus (mTORC1 } \\
\text { inhibitor) and } \\
\text { vatalanib (EGFR-1 } \\
\text { inhibitor) }\end{array}$ \\
\hline $\begin{array}{l}\text { Gonias et al. } \\
2009\end{array}$ & 131I-MIBG \\
\hline $\begin{array}{l}\text { NCT00874614, } \\
\text { USA, } 2009\end{array}$ & 131I-MIBG \\
\hline $\begin{array}{r}\text { NCT 00843037, } \\
\text { Canada, } 2009\end{array}$ & $\begin{array}{l}\text { Sunitinib (VEGF-R, } \\
\text { PDGF-R inhibitor) }\end{array}$ \\
\hline $\begin{array}{l}\text { NCT01155258, } \\
\text { USA, } 2010\end{array}$ & $\begin{array}{l}\text { Temsirolimus (mTORC1 } \\
\text { inhibitor) + vinorelbine } \\
\text { ditartrate (anti-mitotic } \\
\text { chemotherapy) }\end{array}$ \\
\hline $\begin{array}{l}\text { NCT01163383, } \\
\text { USA, } 2010\end{array}$ & 131I-MIBG \\
\hline $\begin{array}{l}\text { NCT01371201, } \\
\text { France, } 2011 \\
\text { (FIRST-MAPP) }\end{array}$ & $\begin{array}{l}\text { Sunitinib (VEGF-R, } \\
\text { PDGF-R inhibitor) }\end{array}$ \\
\hline $\begin{array}{l}\text { NCT01396408, } \\
\text { Canada, } 2011\end{array}$ & $\begin{array}{l}\text { Sunitinib (VEGF-R, } \\
\text { PDGF-R inhibitor) vs } \\
\text { Temsirolimus (mTORC1 } \\
\text { inhibitor) }\end{array}$ \\
\hline $\begin{array}{l}\text { NCT 01340794, } \\
\text { USA, } 2011\end{array}$ & $\begin{array}{l}\text { Pazopanib } \\
\text { hydrochloride } \\
\text { (multi-TKI) }\end{array}$ \\
\hline $\begin{array}{l}\text { NCT0137753, } \\
\text { USA, } 2011\end{array}$ & 131I-MIBG \\
\hline Oh et al. 2012 & $\begin{array}{l}\text { Everolimus (mTORC1 } \\
\text { inhibitor) }\end{array}$ \\
\hline $\begin{array}{l}\text { NCT01635907, } \\
\text { USA, } 2012\end{array}$ & $\begin{array}{l}\text { Dovitinib (FGF-R } \\
\text { inhibitor) }\end{array}$ \\
\hline $\begin{array}{l}\text { Park et al. } \\
2013\end{array}$ & $\begin{array}{l}\text { Fostamatinib Disodium } \\
\text { (TKI) }\end{array}$ \\
\hline $\begin{array}{l}\text { NCT01967576, } \\
\text { USA, } 2013\end{array}$ & $\begin{array}{l}\text { Axitinib (VEGF-R } \\
\text { inhibitor) }\end{array}$ \\
\hline $\begin{array}{l}\text { NCT0183818, } \\
\text { USA, } 2013\end{array}$ & 131I-MIBG \\
\hline $\begin{array}{l}\text { NCT 02302833, } \\
\text { USA, } 2014\end{array}$ & $\begin{array}{l}\text { Cabozantinib (TKI, } \\
\text { c-MET, VEGF-R) }\end{array}$ \\
\hline
\end{tabular}

Patients

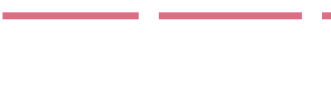

Metastatic NETs including PCs/PGLs

Metastatic and recurrent PCs

Metastatic PCs/PGLs Treatment Completed

Relapsed malignant PCs/PGLs

Recurrent PCs/PGLs

Recurrent or malignant PCs/PGLs

Refractory/Relapsed PCs/PGLs in children

Progressive

malignant PCs/PGLs

Unresected, advanced Treatment Active or metastatic rare tumours including PCs/PGLs

Advanced or progressive malignant PCs/PGLs Malignant PCs/PGLs

Progressive PCs/PGLs

Advanced PCs/PGLs

Advanced PCs Recurrent or primary
unresectable PCs/ PGLS

Refractory PCs/PGLs in children

Advanced or metastatic PCs/PGLs

Treatment Active ।

Treatment Active

Treatment Active

Treatment Completed I

Treatment Active

Treatment Active

Treatment Active

Treatment Active

Treatment Active

\section{Treatment Completed II}

II

II

Expanded Not yet access completed

Not yet completed

II Not yet Not yet completed completed

Treatment Completed II

7

ND

Expanded Not yet Access completed

Treatment Completed II 7

Treatment Active ॥

Treatment Completed II

Treatment Active II had PR $(35 \%$
Not yet completed Not yet completed developed PD within 1 year) Not yet completed Not yet completed ND
VEGF-R, vascular endothelial growth factor-receptor; bFGF, b fibroblast growth factor; NET, neuroendocrine tumours; PC, phaeochromocytomas; PGLs, paragangliomas; ND, no data; $\mathrm{mTOR}$, mammalian target of rapamycin; EGFR-1, endothelial growth factor receptor-1; MIBG, meta-iodobenzylguanidine; PR, partial response; CR, complete response; PD, progression disease; PDGF-R, platelet derived frowth factor; TKI, tyrosine kinase; SD, stable disease; PFS, progression-free survival.
(C) 2017 Society for Endocrinology Printed in Great Britain
Published by Bioscientifica Ltd. 
results, showing strong anti-tumour activity of the dual mTORC1/mTORC2 inhibitor PP242 (Zhang et al. 2015). This was due to the dual effect on both complexes TORC1/ TORC2 inhibiting the compensatory stimulation of the RAS/RAF/ERK pathway which is observed when a single mTORC1 inhibitor such as everolimus is used.

Anti-angiogenic molecules PCs are highly vascular, and aberrant angiogenesis has been associated with a malignant phenotype, especially in patients carrying SDHB gene mutations (Takekoshi et al. 2004). PC tumours express higher levels of VEGF and its receptors (VEGF-R), suggesting they may play an important role in their pathogenesis (Takekoshi et al. 2004). Interestingly, using antibodies against VEGF it was possible to reduce angiogenesis and tumour proliferation in a xenograft mouse model of PCs (Zielke et al. 2002). These findings have led to the evaluation of several angiogenesis inhibitors as therapeutic agents in malignant PGs/PGLs.

Thalidomide is an anti-angiogenic agent specifically targeting VEGF and the basic fibroblast growth factor (FGF) receptors. Only one phase II trial has been conducted, but due to the limited number of patients studied $(n=3)$ it is impossible to draw definite conclusions regarding the efficacy of thalidomide in PC patients (Kulke et al. 2006).

Sunitinib, a potent oral multi-TK inhibitor with antiangiogenic and anti-tumour activity, has demonstrated potential benefit in metastatic SDH- or VHL-mutated PCs (Jimenez et al. 2009, Saito et al. 2012). In cell lines, sunitinib decreased cell proliferation in vitro by targeting cell cycle, DNA metabolism and cell organisation genes (Cassol et al. 2014). In 17 patients with progressive metastatic PCs/ PGLs, sunitinib was associated with a significant reduction in tumour size, a 30\% decrease in ${ }^{18}$ Fluoro-deoxyglucose (FDG)-PET/CT uptake, and a median overall survival of 26.7 months with a PFS of 4.1 months (95\% CI: 1.4-11.0) (Ayala-Ramirez et al. 2012a). Most patients who experienced a clinical benefit were carriers of the SDHB mutation (Hahn et al. 2009, Ayala-Ramirez et al. 2012a). In VHL patients with metastatic PCs/PGLs, treatment with sunitinib for 6 months was associated with normalisation of patients' performance status and blood pressure, significant tumour shrinkage and reduction of plasma noradrenaline and chromogranin A levels (Jimenez et al. 2009). An ongoing phase II study (FIRST-MAPP) aims to determine the efficacy of sunitinib on PFS at 12 months in progressive malignant PCs/PGLs.

Vandetanib, which inhibits VEGF-R2, VEGF-R3 and VEGF-R1 and, at higher concentrations, EGF-R, has demonstrated promising results in both in vitro and in vivo studies (Brave et al. 2011); it is known to be active in medullary thyroid carcinomas harbouring RET mutations (Vitagliano et al. 2011). The coexistence of medullary thyroid carcinoma and PCs in MEN2 syndromes suggests that vandetanib could also be a good candidate drug in PCs/PGLs.

Hypoxic-inducible factor inhibitors Although no data have been reported in human malignant PCs with these agents, hypoxic-inducible factor (HIF) inhibitors have shown marked anti-tumour activity in various human tumour xenografts in mice (Semenza 2007). Under normoxic conditions, site-specific hydroxylation of HIF- $1 \alpha$ allows recognition by the VHL protein resulting in proteasomal degradation. Under hypoxic conditions, hydroxylation of the HIF-1a subunit is suppressed, leading to increased levels of HIF that regulate the expression of many target genes. (Jochmanová et al. 2013, Yang et al. 2015).

Recently, the selective HIF-2 antagonist, PT2399, has been shown to induce tumour regression in mouse models of VHL-defective clear cell renal carcinoma characterised by inactivation of the VHL gene and subsequent activation of HIF-2 (Cho et al. 2016). PT2399 had greater activity than sunitinib, was active in sunitinibprogressing tumours, and was better tolerated (Chen et al. 2016). These data suggest that this drug may be useful in PCs/PGLs associated with HIF-2a mutations.

Heat shock protein-90 (HSP90) This multichaperone ATP-dependent complex is responsible for protein folding and plays an important role in the stability and function of a number of oncoproteins and telomerase (Banerji 2009). Overexpression of HSP90 has been observed in malignant PCs, and it has been identified as a promising therapeutic target (Banerji 2009). In a xenograft mouse model, the use of two different HSP90 inhibitors, benzoquinone ansamycin 17-allylamino-17-demethoxygeldanamycin (17-AAG), and the second-generation ganetespib, demonstrated significant inhibition of proliferation and migration in PC cell lines and induced degradation of HSP90. In these metastatic models of PCs, both inhibitors achieved reduction of tumour burden and reduced cell survival (Giubellino et al. 2013b). HSP90 may thus represent a potential therapeutic target for metastatic PCs/PGLs, although the relatively non-specific mode of action my limit its use.

Published by Bioscientifica Ltd. 
HER2/neu inhibitors HER2 is a tyrosine kinase receptor involved in the cell growth and differentiation and it leads to the synthesis of HIF when activated. HER2 is overexpressed in malignant PCs and is associated with tumour metastases and resistance to treatment; however, no trials have been conducted to date using HER2/neu inhibitors (Tavangar et al. 2010, Mohammed et al. 2014).

Other agents Carboxypeptidase $\mathrm{E}$ (CPE) is a prehormone-processing enzyme expressed in different types of cancer including NETs, mainly of the lung and pituitary (Murthy et al. 2010). Extremely high CPE mRNA copy numbers of the N-terminal splice isoform variant were found in various human metastatic tumour cell lines, including metastatic PCs. Interestingly, this high copy number in tumours was shown to predict tumour recurrence and/or metastatic disease, suggesting that CPE could be a potential therapeutic target in metastatic PCs.

NVP-AEW451 acts as IGF-1 receptor antagonist that significantly reduced mouse PC cell proliferation and tumour cell viability, albeit at relatively high doses. However, at suboptimal doses this agent led to a compensatory upregulation of ERK and mTORC1 signals whereas PI3K/AKT inhibition remained stable (Nölting et al. 2012). More recently, LB1, a small molecule inhibitor of serine/threonine protein phosphatase $2 \mathrm{~A}$, inhibited mouse PC cells in vitro and in vivo in a mouse model of metastatic PCs, either alone or in combination with temozolomide (Martiniova et al. 2011).

Temozolomide, an oral derivative of dacarbazine, was studied as monotherapy in 15 patients with metastatic PCs/PGLs. There were five partial responses (33\%), seven (47\%) patients experienced stable and three (20\%) developed progressive disease after a median follow-up of 35 months. Partial responses were observed only in patients with SDHB mutations. The silencing of O(6)-methylguanine-DNA methyltransferase (MGMT) expression as a consequence of MGMT promoter hypermethylation in SDHB-mutated tumours may explain this finding (Hadoux et al. 2014).

Another promising therapeutic agent could be the use of lipophilic statins (simvastatin and fluvastatin) either alone (Fliedner et al. 2014) or in association with 13-cisretinoic acid (Nölting et al. 2014). Statins can induce apoptosis of PC cells through inhibition of MAPK-1 and -3 phosphorylation in aggressive mouse PC cells in vitro (Fliedner et al. 2014, Nölting et al. 2014).

In vitro studies in tissues as well as in cell cultures have revealed the expression of somatostatin receptors
(SSTRs) (particularly subtype 2A and 3) in PCs/PGLs and have suggested that by targeting SSTRs it might be able to control tumour growth and secretion (Ziegler et al. 2009, Elston et al. 2015). However, these results have not been widely confirmed, as only some case series have shown symptom and tumour control in a subset of patients (van Hulsteijn et al. 2013, Elshafie et al. 2014). More promising results with radioisotopes bound to synthetic somatostatin analogues (SSAs) in patients with high tumoural uptake have been published, especially significant in the light of the impressive results of peptide receptor radiotherapy (PRRT) reported in the NETTER-1 study in patients with midgut neuroendocrine tumours (Strosberg et al. 2017). To date, PRRT using ${ }^{90}$ Yttrium or ${ }^{177}$ Lutetium-labelled SSAs has been evaluated in only a limited number of PCs/ PGLs. In a total of 25 patients from three different clinical trials including patients with progressive or metastatic PCs/PGLs, four patients showed a partial response and 14 had stable disease, suggesting that PRRTs could be an effective therapeutic option for these tumours (van Essen et al. 2006, Zovato et al. 2012, Puranik et al. 2015). Larger studies including hereditary and non-hereditary PCs/PGLs are needed to identify which PCs/PGLs can be best treated using this therapy, and whether PRRT should be used alone or with other treatment modalities.

Radionuclide therapy with ${ }^{131}$ I-metaiodobenzylguanidine (MIBG) has also been used either as a single or sequential cumulative doses administered in patients with significant tumour burden and adequate ${ }^{123}$ I-MIBG uptake on diagnostic imaging (Mukherjee et al. 2001, Kaltsas et al. 2005b). A recent meta-analysis of the efficacy of ${ }^{131}$ I-MIBG-therapy in malignant PCs/PGs showed that disease control and partial hormonal responses were obtained in 50 and $40 \%$ of patients, respectively (van Hulsteijn et al. 2014). In a multicentre registry, partial response or stability of the disease according to the RECIST criteria was achieved in $85 \%$ of patients, with minor side effects in approximately $90 \%$ of patients (Yoshinaga et al. 2014). However, there may also be long-term sequelae such as myelodysplastic disorders and haematological malignancies (Sze et al. 2013). Nevertheless, the prognosis for malignant PCs/PGLs still remains relatively poor, highlighting the need for the development of new personalised therapeutic strategies.

In summary, for metastatic PCs/PGLs that do not respond or cannot be treated with the current established therapies, radionuclide therapy with a labelled SSTR-active analogue or ${ }^{131}$ I-MIBG should be considered, depending on the diagnostic uptake. At present, it is not possible to differentiate between these two possible therapies. MTT

Published by Bioscientifica Ltd 
with a TKI such as sunitinib is another option. However, MTT using monotherapy seems to show limited clinical meaningful benefit, and it is suggested that in the longer term combination MTT with a TKI, an mTOR inhibitor plus possibly other agents (statins, retinoic acid, HSP inhibitors, etc), may be most effective. It is also likely that molecular analysis of individual tumours may guide treatment in the future.

\section{Adrenocortical carcinoma}

\section{Introduction}

Adrenocortical carcinoma (ACC) is a rare tumour with an estimated incidence of 0.7 new cases $/ 1,000,000$ per year (Assie et al. 2014). The genomic landscape of ACCs has revealed that it is a biologically and genetically heterogeneous malignancy with transcriptome clusters associated with distinct drugable clinical behaviour (Assie et al. 2014). Various molecular agents used in recent years in clinical trials as well as in vitro studies for treating patients with ACC have been already well-described in a recent review (Creemers et al. 2016). Therefore, here we summarise most of these data as well the newer studies published since this review in Tables 2 and 3.

\section{Current treatment based on clinical trials}

Currently 'R0', complete surgical resection, is the gold standard treatment for non-metastatic ACC or following local recurrence (Berruti et al. 2012b). Mitotane is the only FDA-approved drug for locally advanced inoperable and metastatic disease displaying single-agent activity of $10-30 \%$ tumour response rates based on its adrenolytic action, albeit with a high toxicity profile (Veytsman et al. 2009). The only prospective phase III randomised clinical trial, FIRM-ACT, showed that in advanced ACCs mitotane combined with etoposide, doxorubicin and cisplatin (EDPM) provided some additional clinical benefit compared to mitotane plus streptozocin alone, but was associated with more serious adverse events (Fassnacht et al. 2012). A further prospective study evaluating mitotane vs. placebo in high-risk for recurrence patients, ADIUVO, is currently under way (Terzolo et al. 2007) (https://www.epiclin.it/adiuvo).

\section{Molecular profile}

The main signalling pathways involved in ACC tumourigenesis include the PI3K/Akt/mTOR cascade and the RAS-MAPK pathway, both activated by the IGF-1R when occupied by IGF2 (Pollak 2008). IGF2 mRNA and protein are overexpressed in more than $90 \%$ of ACCs (Ribeiro et al. 2012). Genetic studies have identified alterations in the FGF-R cascade (Laurell et al. 2009), and overexpression of VEGF-R, PDGF-R, EGF-R, and the FGF-R signalling pathways (Xu et al. 2011, Wang et al. 2012). Preclinical studies support the idea that mTOR inhibitors can upregulate Akt phosphorylation in ACCs (Liu et al. 2009, De Martino et al. 2014).

Other key molecular events contributing to the formation of ACC are tumour protein 53 (TP53) inactivating mutations (Libè et al. 2007) and constitutive activation of the Wnt/ $\beta$-catenin signalling pathway via activation of the $\beta$-catenin gene (CTTNB1) (Tissier et al. 2005). The increased occurrence of adrenocortical tumours in Li-Fraumeni and Beckwith-Wiedemann syndromes, as well as in the Carney complex, has highlighted the roles of susceptibility genes: TP53, IGF2, and protein kinase cAMP-dependent type I regulatory subunit alpha (PRKAR1A) (de Joussineau et al. 2012), respectively.

Alterations in the nuclear transcription steroidogenic factor 1 (SF-1) are also involved (Val et al. 2003, Duregon et al. 2013). SF-1 induces proliferation of ACC cell lines and tumour growth in vivo (Doghman et al. 2009) and its increased expression has been associated with a worse prognosis (Sbiera et al. 2010). SF-1 inhibitors in ACC cell lines inhibited cell proliferation associated with SF-1 overexpression along with steroid hormone oversecretion and CYP21 and CYP17 mRNA expression (Doghman et al. 2010).

Interferon- $\beta$ (INF- $\beta$ ) may exert an inhibitory effect in vitro on ACC cell lines and primary cultures of human ACC (van Koetsveld et al. 2013), and increases sensitivity of ACC cells to mitotane (van Koetsveld et al. 2013).

Topoisomerase-a2 (TOP2A), a gene consistently overexpressed in ACC, is involved in cellular invasion as it regulates anchorage-independent growth and invasion. Several TOP2A inhibitors have been screened for their anti-proliferative activity in ACC cells (Jain et al. 2013).

\section{Molecular therapy}

Different drugs targeting the molecular pathways described above have been tried in clinical trials phase I-III (Table 2) or in vivo and in vitro studies (Table 3).

IGF-1R inhibitors including mTOR inhibitors and monoclonal anti-IGF-1R antibodies, as well as antiangiogenic agents, have been used as monotherapy in

Published by Bioscientifica Ltd. 


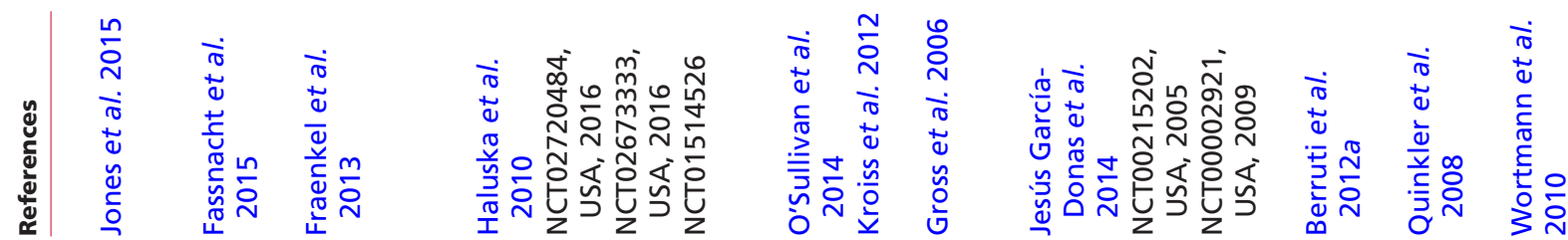
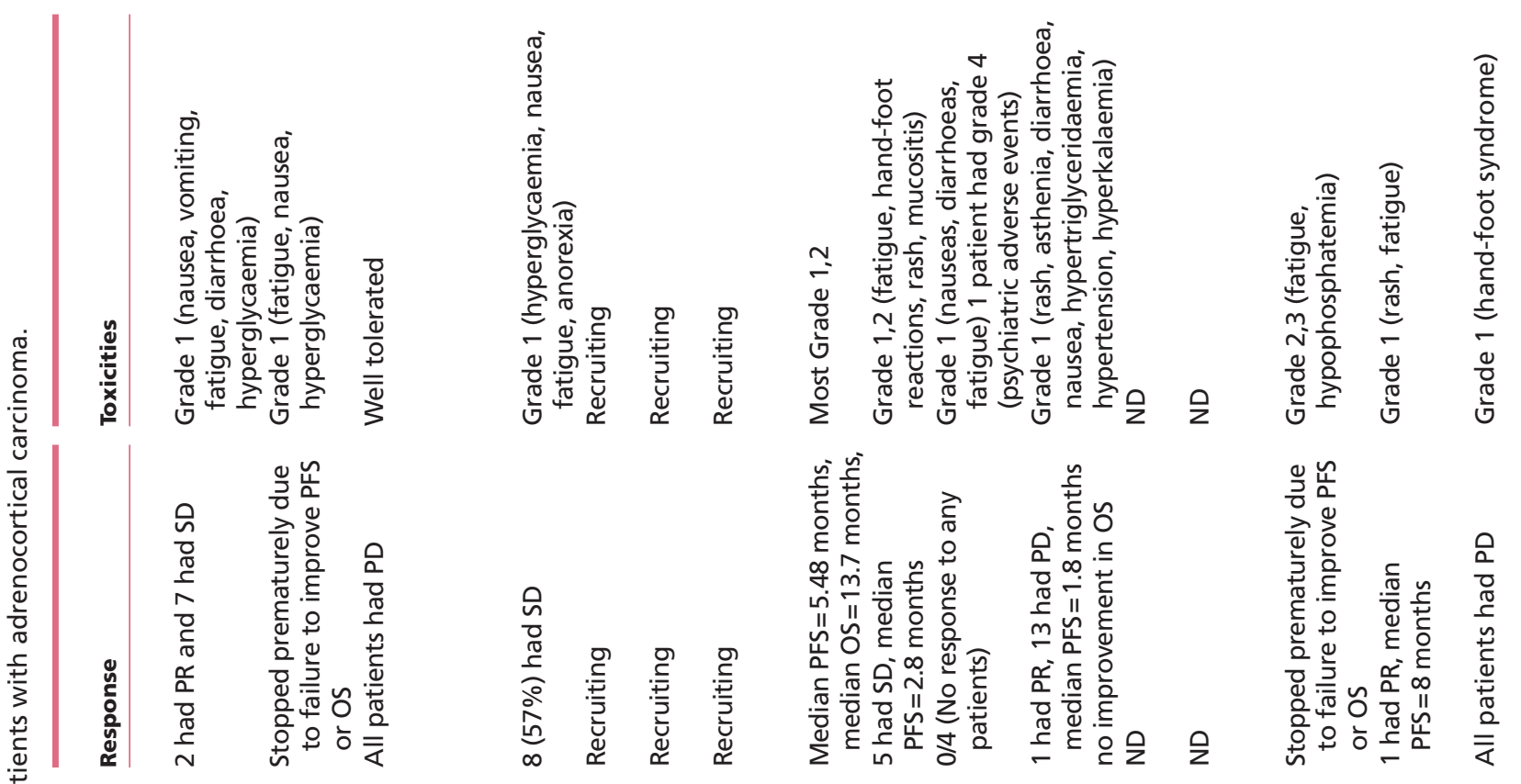

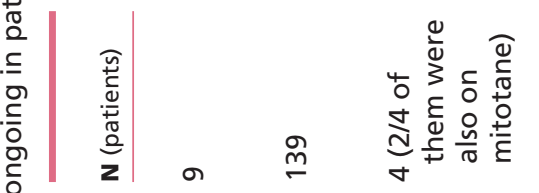

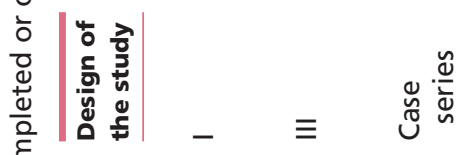
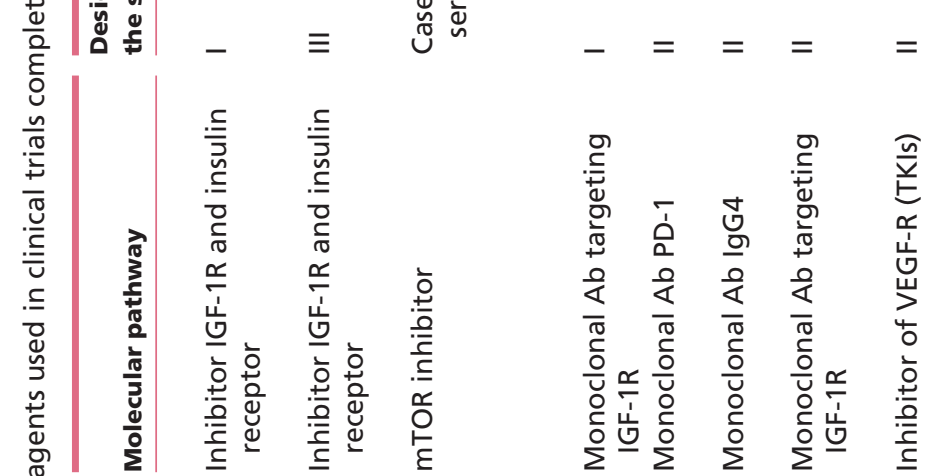

$\pm \frac{2}{2} \frac{a}{2}$

$m \stackrel{m}{m} \sigma$

$=\sum \stackrel{2}{z} \div \quad$

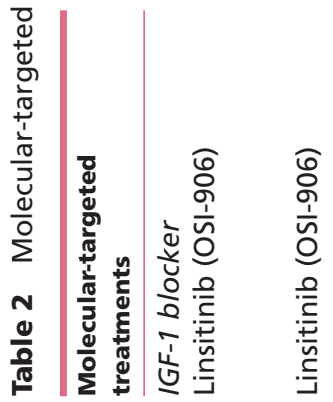

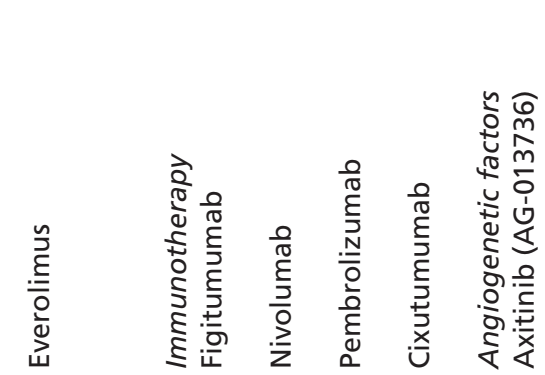

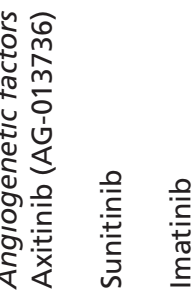
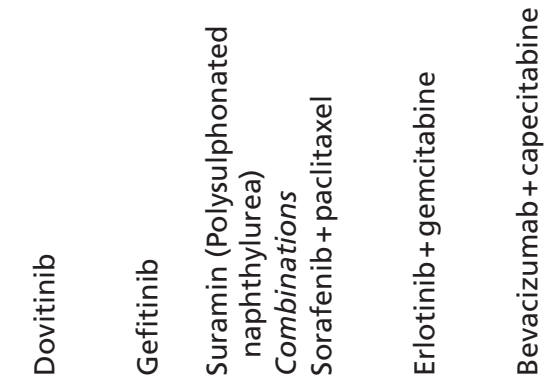


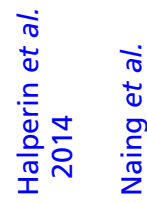

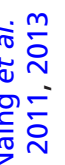
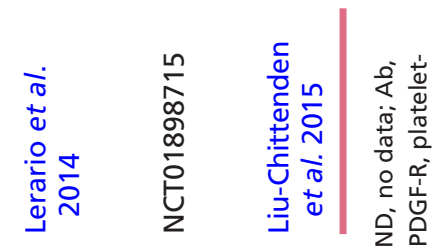

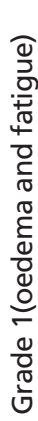
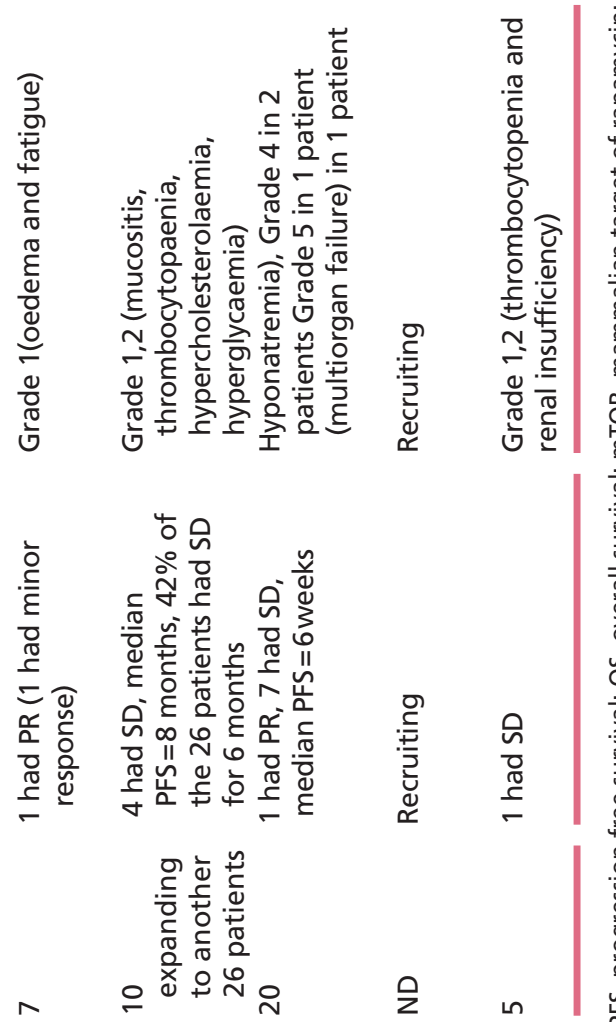

เก

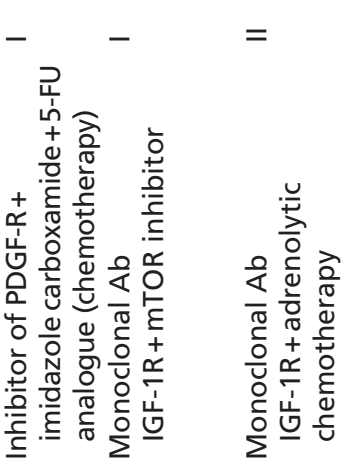

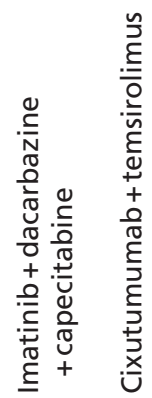

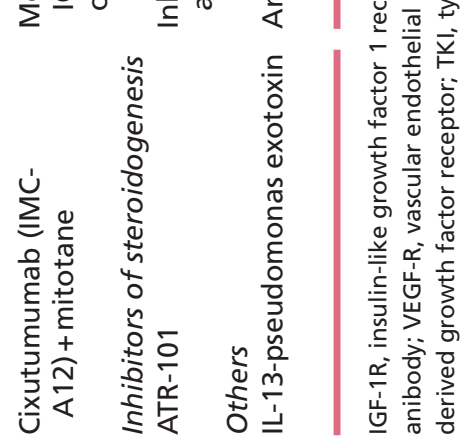

http://erc.endocrinology-journals.org DOI: 10.1530/ERC-16-0542
๑) 2017 Society for Endocrinology Printed in Great Britain patients with advanced progressive ACCs, albeit without promising results. The most probable explanation for this finding is that the inhibition of IGF-R1 leads to the compensatory activation of the MEK/ERK pathway leading to sustained activation of mTOR (Xu et al. 2016). FGF-R4 overexpression and amplification (identified in $13 \%$ of paediatric and $30 \%$ of adult ACCs) was associated with a worse outcome, supporting the potential role of selective FGF-R inhibitors in ACC treatment (West et al. 2007, Brito et al. 2012).

Treatments combining different molecular targeting agents or a molecular targeting agent with classical chemotherapy have been also studied. Preclinical data suggest increased efficacy of sunitinib when combined with an ERK pathway inhibitor (Lin et al. 2012). However, the plasma levels of sunitinib might be reduced by mitotane-induced CYP3A4 activity, thereby attenuating its anti-tumour activity when used in combination (Kroiss et al. 2012). Co-inhibition of IGF-R1 and EGFR has also shown promising results in ACC cell lines.

Based on the premise that many ACCs require substantial intracellular cholesterol as a substrate for steroidogenesis, drugs disrupting cholesterol uptake might have therapeutic potential. A selective inhibitor of acetyl-CoA acetyl-transferase 1 (ACAT1), which catalyses cholesterol ester formation from cholesterol and long-chain fatty acyl-CoA, has been investigated in a phase II study of patients with advanced ACC (Aung Naing et al. 2015).

Other molecules including inhibitors of pololike kinase (PLK-1), such as BI-236 (Bussey et al. 2016), inhibitors of TOP2A such as aclarubicin (Jain et al. 2013) and IL-13-pseudomonas exotoxin (Liu-Chittenden et al. 2015), are attractive strategies in ACC. Three other compounds that have been investigated in preclinical ACC models are thiazolidinediones (TZDs), HSP90 inhibitors, and decitabine, a DNA methyl-transferase inhibitor, with all showing inhibition of ACC cell proliferation (Suh et al. 2010, Huang et al. 2014).

In clinical practice, the gold standard treatment for metastatic ACC is cytoreductive surgery along with mitotane in combination with chemotherapy (EDP) according to the FIRM-ACT study. For progressive disease, despite these treatments their outlook remains still grim, with little assistance as yet from monotherapy with MTTs. The combination of imatinib with dacarbazine and capecitabine, or cixutumumab and temsirolimus, has shown encouraging clinical responses, albeit with considerable adverse events. As yet, MTTs have had little impact on the therapy of this sinister disease.

Published by Bioscientifica Ltd. 
Table 3 Molecular-targeted agents used in in vitro/in vivo studies of adrenocortical carcinoma.

Molecular-targeted treatments

Everolimus

Molecular pathway

mTOR inhibitor

Angiogenetic factors

Sunitinib

Multiple TKIs

Erlotinib

Anti-EGF-R

Combinations

Sorafenib + everolimus

Sorafenib + everolimus
Sirolimus + mitotane

mTORC1/C2 and adrenolytic treatment

TKIs + ERC inhibitor (Raf/MEK inhibitor)

EGF-R inhibitor + IGF-1R inhibitor

Interferon-b + adrenolytic chemotherapy

SR-BI inhibitors

High-density lipoprotein (HDL) nanoparticles

Others

Alkyloxyphenol and isoquinolinone

Bi-2536

Aclarubicin

SF-1 inhibitors

Inhibitors of PLK-1

TOP 2A inhibitors
VEGF-R2, VEGF-R3, PDGF-R and RAF-1 + $m$ TOR inhibitors VEGF-R2, VEGF-R3, PDGF-R and RAF-1 + mTOR inhibitors

In vitrolln vivo
In vitro ACC cell
lines in
childhood

In vitro $(\mathrm{H} 295 \mathrm{R}$ cells lines)

In vitro (H295 and SW13 cells lines)

\section{In vitro (SW13} cells lines)

In vitro (SW13 and H295R cells lines) In vivo SW13
xenografts mices

In vitro (H295 and SW13 cells lines)

In vitro (H295R and SW13 cells lines)

In vitro $(\mathrm{H} 295 \mathrm{R}$ and SW13 cells lines)

In vivo (ACC mice xenografts)

In vitro (2 ACC cells lines)

In vitro (H295R and SW13 cells lines)

In vitro $(\mathrm{H} 295 \mathrm{R}$ and SW13 cells lines)

In vitro (H295R and SW13 cells lines)

In vitro $(\mathrm{H} 295 \mathrm{R}$ and SW13 ACC

\section{Response}

Inhibition of cell proliferation and reduced tumour cell growth

Reduce cell proliferation Lin et al. 2012 by $20 \%$

Reduction of cell viability in ACC lines

Significant apoptosis Inhibition of cell viability in SW13 cells

Increased apoptosis

Synergistic growth inhibition of SW13 xenografts mices

Mitotane significantly

inhibited cell

De Martino et al. proliferation. Sirolimus showed statistically significant additive effects

Decrease proliferation by $68 \%$ and $64 \%$ in H295R and in SW13 cells

Inhibition of cell viability Xu et al. 2016 and increase apoptosis.

Antitumor activity in vivo

Inhibitory effect on cell number and cortisol secretion.

Gagliano et al. 2015

Berruti et al. $2012 b$

Mariniello et al. 2012 2016

Lin et al. 2012

Enhanced the apoptosis induced by etoposide, cisplatin or mitotane and SW13 cells lines)
Inhibitory effect on both SF-1-positive and -negative cells

$70 \%$ loss of viability

Decrease of the proliferation and tumour spheroid size $(P<0.05)$.
Van

Koetsveld et al. 2013

Subramanian et al. 2016

Doghman et al. 2010

Bussey et al. 2016

Jain et al. 2013

IGF-1R, insulin-like growth factor 1 receptor; mTOR, mammalian target of rapamycin; ACC, adrenocortical cancer; TKI, tyrosine kinase inhibitor; VEGF-R, vascular endothelial growth factor receptor; EGF-R, epidermal growth factor; receptor; FGF-R, fibroblast growth factor receptor; PDGF-R, plateletderived growth factor receptor; ERK, extracellular signal-regulated kinases (MAP kinases), SR-BI, scavenger receptor class B type I; SF-1, steroidogenic factor 1; PLK1, Polo-like kinase 1TOP2A, topoisomerase (DNA) II Alpha.

http://erc.endocrinology-journals.org DOI: 10.1530/ERC-16-0542
(C) 2017 Society for Endocrinology Printed in Great Britain
Published by Bioscientifica Ltd 


\section{Pituitary tumours}

\section{Introduction}

Pituitary tumours are for the most part benign monoclonal adenomas presenting with excessive hormone secretion and/or tumour mass effects, albeit a small minority may become frankly malignant (Melmed et al. 2003). Although surgical resection remains the mainstay of therapy for macroadenomas causing compression of neurovascular structures, pharmacotherapy can play a crucial role in their treatment. Recent advances in the genetic and molecular analysis of pituitary tumours have provided new insights into the growth patterns and secretory function of these tumours, and have allowed for a more precise characterisation of individual lesions.

\section{Molecular profile}

The PI3K/Akt and MAPKs pathways are the two major signalling pathways responsible for regulating cell growth and proliferation, which are activated by growth factor receptors (McCubrey et al. 2007). The PI3K/Akt/ mTOR pathway is also upregulated in pituitary tumours (Muşat et al. 2005, 2010, Cakir et al. 2009). Notch-3 and Jagged-1 have been implicated in the pathogenesis of human non-functioning pituitary adenomas, thereby providing a potential therapeutic target for the medical treatment of these tumours. Several elements of the Notch pathways have also been identified in the transcriptome of prolactinomas and multi-hormonal pituitary adenomas (Jiang et al. 2012). Hedgehog (Hh) signalling exerts differential effects on pituitary cell growth (with stimulatory effects on progenitor cells and inhibitory effects in differentiated cells), and is able to modulate hormone secretion and proliferation in pituitary tumours. Moreover, exogenous treatment with Hh proteins in cell cultures has been shown to increase hormone secretion from pituitary tumour cells, reflecting their role as hypophysiotropic factors that regulate pituitary hormone release in normal and tumoural tissue cells (Yavropoulou et al. 2015). More specific targeting treatment depends on the type of pituitary adenoma.

Approximately, 30-45\% of pituitary tumours invade the cavernous or sphenoid sinus (Zada et al. 2011), and a significant number are considered as aggressive based on their resistance to conventional treatment or recurrence during the follow-up (Raverot et al. 2012) (Fig. 2). Some rare aggressive tumours that develop metastases are considered as carcinomas (Heaney et al. 2011, Batisse et al. 2013, Chatzellis et al. 2015) and cannot be controlled by any available treatment (McCormack et al. 2009, Heaney et al. 2011, Jouanneau et al. 2012, Raverot et al. 2012). Pituitary carcinomas are rare $(0.2 \%)$, defined by the presence of systemic or cerebrospinal metastases (Kaltsas et al. 2005a, Heaney et al. 2011). The 2004 WHO classification considered all benign tumours as either typical adenomas or atypical adenomas tumours showing 'borderline or uncertain behaviour' (Keblad et al. 2007). The latter tumours exhibited invasive growth, high mitotic index, an elevated mitotic index, a Ki-67 labelling index $(\mathrm{LI})>3 \%$ as well as extensive nuclear staining for p53 (Del Basso De Caro et al. 2016, Kim et al. 2016). In recent studies, pituitary tumour recurrence could be predicted by using mitoses, invasion, Ki-67 labelling index (>3\%), or extensive p53 immunoreactivity ( $\geq 20 \%$ ) (Del Basso De Caro et al. 2016, Kim et al. 2016). However, it should be noted that the revised WHO classification, due for publication in 2017, has rejected the 'typical/ atypical' classification, and instead emphasises staining with Ki-67, and the degree of invasiveness as revealed by surgical and radiological findings; p53 staining should be reserved for special cases, whereas electron microscopy is rarely of value.

\section{Current treatments for aggressive tumours}

Because of the rarity of these tumours, data from randomised controlled studies comparing the efficacy and safety of

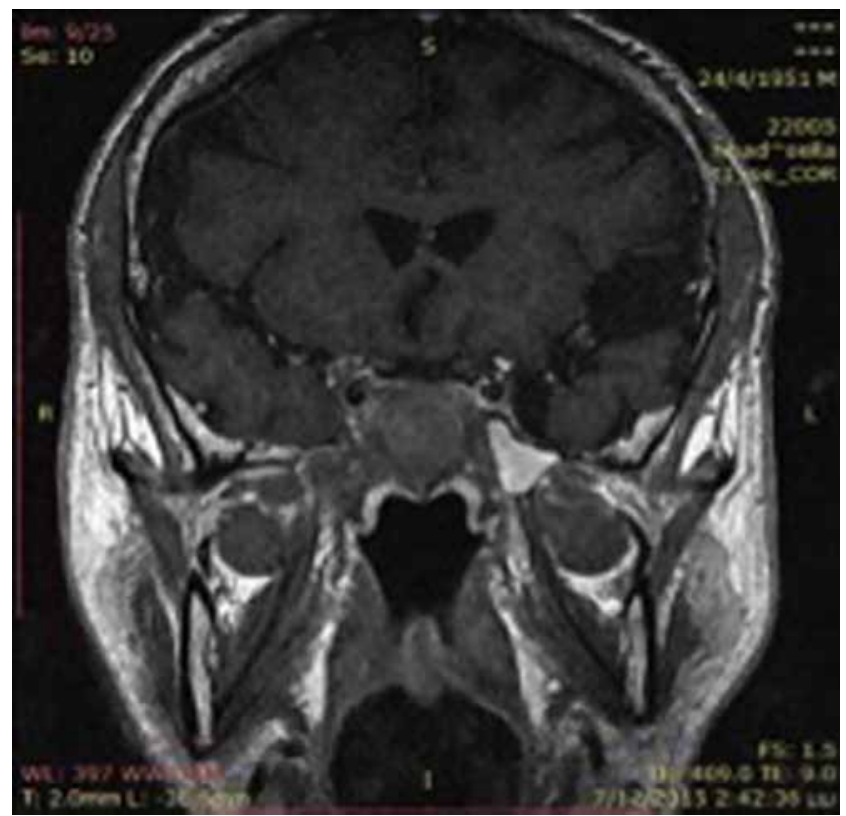

Figure 2

Post-contrast T1-sequence MRI showing an aggressive pituitary macroadenoma recurring after initial surgery.

Published by Bioscientifica Ltd 
the various therapeutic modalities are lacking. Patients with incompletely resected aggressive tumours may require further surgery and additional medical treatment with SSAs and/or cabergoline. Recently, dopamine agonist therapy in non-functioning pituitary adenomas with post-surgical remnants showed stabilisation or shrinkage of the tumour (Greenman et al. 2016). Conventional or targeted radiotherapy is worthy of consideration, whereas conventional systemic chemotherapy has been shown to have an unpredictable and generally minor response (Kaltsas et al. 2005b, Raverot et al. 2012).

Somatostatin receptor expression is found within normal pituitary cells including corticotrophs and lactotrophs, and binding of somatostatin to its receptor triggers a G-protein-mediated signal cascade that inhibits secretory function in these cells. The two long-acting SSAs in use today are octreotide and lanreotide. More recently, the somatostatin analogue pasireotide, showing increased binding affinity for SSTR-1, 3 and 5, was compared to octreotide and lanreotide, and has apparently shown superior efficacy in the biochemical control of patients with acromegaly (Colao et al. 2014). Pegvisomant, a pegylated analogue of human GH, is currently the only GH-receptor antagonist approved by the FDA available for the treatment of acromegaly. It directly competes for receptor binding with plasma GH resulting in decreased IGF-1 production (van der Lely et al. 2012).

Recent clinical trials have demonstrated the successful application of temozolomide in pituitary carcinomas and aggressive pituitary tumours, and this agent has shown to be efficient in controlling tumour progression and metastasis in approximately 50\% of cases (McCormack et al. 2009, McCormack et al. 2011, Raverot et al. 2012). Despite these encouraging results with temozolomide showing longterm control in $40 \%$ of patients (Bush et al. 2010, Losa et al. 2010, Raverot et al. 2010), some tumours develop secondary resistance during the follow-up (McCormack et al. 2009, Raverot et al. 2010). The development of new therapeutic options is particularly necessary for pituitary carcinomas resistant to temozolomide (Jouanneau et al. 2012). Some case reports suggest the need to combine temozolomide with other chemotherapeutic agents such as capecitabine (Thearle et al. 2011) or with the new SSA pasireotide (Bode et al. 2010).

\section{Molecular targeted treatment}

A number of preclinical and clinical studies have suggested that new MTT may also be useful in controlling pituitary tumour growth. The anti-proliferative effect of an mTOR inhibitor on different pituitary cell lines or primary cultures has been demonstrated in vitro (Cerovac et al. 2010). In vitro data have also shown an effect of everolimus on cell viability in cell cultures from non-functioning pituitary adenomas (Zatelli et al. 2010). Furthermore, a mutation of the mTOR pathway, STK11, was found in a woman with an adrenocorticotrophic-secreting pituitary carcinoma refractory to surgical resection, radiation, and chemotherapy with capecitabine and temozolomide. After the combination of radiation and everolimus, significant clinical improvement and radiological stability was obtained, although the patient died of metastatic disease (Vlotides et al. 2008).

There is also some evidence supporting the role of the EGF-R pathway in pituitary proliferation (Vlotides et al. 2008, Cooper et al. 2011), and the potential use of TKIs (Fukuoka et al. 2011) for targeted therapy in pituitary tumours. Anecdotal cases have shown control of tumour growth by the administration of bevacizumab, an antiVEGF agent, in a single patient (Ortiz et al. 2012), and in another case 26-month disease control was observed (Ortiz et al. 2012). The previously highlighted importance of EGF and its receptor EGF-R has also prompted research concerning the use of TKIs, especially the EGFR inhibitor gefitinib, as a targeted medical therapy for ACTHadenomas, demonstrating promising in vitro results (Fukuoka et al. 2011).

Recently, an exhaustive exome-wide screening has led to the identification of somatic mutations in the ubiquitin-specific protease 8 (USP8) in ACTH-producing adenomas (Reincke et al. 2015). This gene codes for a protein with deubiquitinase (DUB) activity that inhibits the lysosomal degradation of EGF-R (Mizuno et al. 2005). Mutated USP8 leads to higher DUB activity than the wild type, therefore increasing EGF-R stability and enhancing EGF-R-induced pro-opiomelacortin (POMC) transcription and ACTH secretion. The absence of USP8 mutations in other types of pituitary tumours, including silent ACTH-producing adenomas, suggests that these alterations are specific traits of secretory corticotroph adenomas causing Cushing's disease (Reincke et al. 2015). The high prevalence of mutations in USP8 in patients with Cushing's disease, but not in any other pituitary adenomas, provides a plausible explanation for the dependence of corticotrophinomas on EGF-R signalling and suggests that the mutational status of USP 8 can be used to stratify the patients for targeted therapies against EGFR (Fukuoka et al. 2011, Ma et al. 2015). In vitro studies showed that targeting EGF-R to mouse corticotroph cell nuclei resulted in higher POMC expression and ACTH

Published by Bioscientifica Ltd 
secretion, both of which were inhibited by gefitinib (Fukuoka et al. 2011).

The cyclin-dependent kinase (CDK) inhibitor p16 is downregulated in pituitary tumours, probably by methylation of its promoter, leading to a loss of suppression of CDK4 and CDK6 and progression through the checkpoint inhibition into the cell-cycle $S$ phase (Farrell \& Clayton 2003). Recently, CDK4/6 antagonists have entered into clinical practice, with palbociclib showing potential in the treatment of breast cancer, causing either cellular quiescence or senescence (Finn et al. 2016). It will be of interest to see whether such treatment will be of value in the therapy of aggressive pituitary adenomas or carcinomas. However, it should be noted that corticotroph tumours are more dependent on alterations in p27, cyclin $\mathrm{E}$ and CDK2; therefore, these tumours may be less likely to respond (Dworakowska \& Grossman 2012).

Although PRRT directed against SSTR2 and SSTR5 subtypes using either ${ }^{90}$ Ytrium and most recently ${ }^{177}$ Lutetium could be used for aggressive or recurrent pituitary tumours expressing SSTRs, this modality has not been significantly used in pituitary carcinomas. There are only few case reports in the literature demonstrating the use of PRRT in atypical or aggressive pituitary adenomas or carcinomas. ${ }^{177}$ Lutetium DOTATOC improved local complications for more than 8 years after ineffective surgery and gamma-knife therapy in a patient with a non-functioning pituitary macroadenoma (Komor et al. 2014). In another case, a patient with an aggressive, giant GH-secreting tumour refractory to all treatments developed a partial biochemical remission and reduction in tumour mass using ${ }^{90}$ Y-DOTATATE (WaligórskaStachura et al. 2016). In a further case series including one patient with a pituitary carcinoma and two with atypical adenomas, results were inconsistent as stable disease was achieved in the sole patient with the more slowly progressive tumour (Maclean et al. 2014). Furthermore, a patient with a giant prolactinoma, refractory to medical treatment, showed substantial tumour shrinkage after four cycles of ${ }^{111}$ Indium-DTPA-octreotide (Baldari et al. 2012), but this radiobiological therapy is far from ideal.

Overall, for malignant pituitary tumours there is limited evidence for the role of MTT, although TKIs such as geftinib and mTOR inhibitors such as everolimus have demonstrated promising results in vitro and in vivo in animals. However, as these tumours exhibit SSTRs, treatment with PRRT appears an attractive option, probably best in the context of a therapeutic trial. Nevertheless, in desperate situations there may be a place for attempted therapy with either gefitinib or everolimus. The potential role of chemosensitisation with temozolomide to enhance the therapeutic response could also be explored in the future.

\section{Parathyroid carcinoma}

\section{Introduction}

Most cases of primary hyperparathyroidism are sporadic, but may occur as a part of hyperparathyroidism-jaw tumour syndrome (HJTS), or multiple endocrine neoplasia type-1 or 2A syndromes (McClenaghan et al. 2015). Histologically, primary hyperparathyroidism is caused by a single adenoma in $80-85 \%$ of cases, by hyperplasia or multiple adenomas in $15-20 \%$ of cases, and by a carcinoma in $0.5-5 \%$ of cases (Givi \& Shah 2010, Mohebati et al. 2012) (Fig. 3). Differentiation of parathyroid carcinoma from parathyroid adenoma, especially atypical adenoma, can be very difficult in some cases (Mohebati et al. 2012).

\section{Molecular profile}

Gene expression profiling of parathyroid adenomas and carcinomas may provide an explanation for the formation of parathyroid carcinomas and aid in the differential diagnosis of these lesions (Arvai et al. 2012).

To date, mutations of one hyperparathyroidism gene (HRPT2, also known as CDC73) has been established as the underlying genetic mechanism in parathyroid

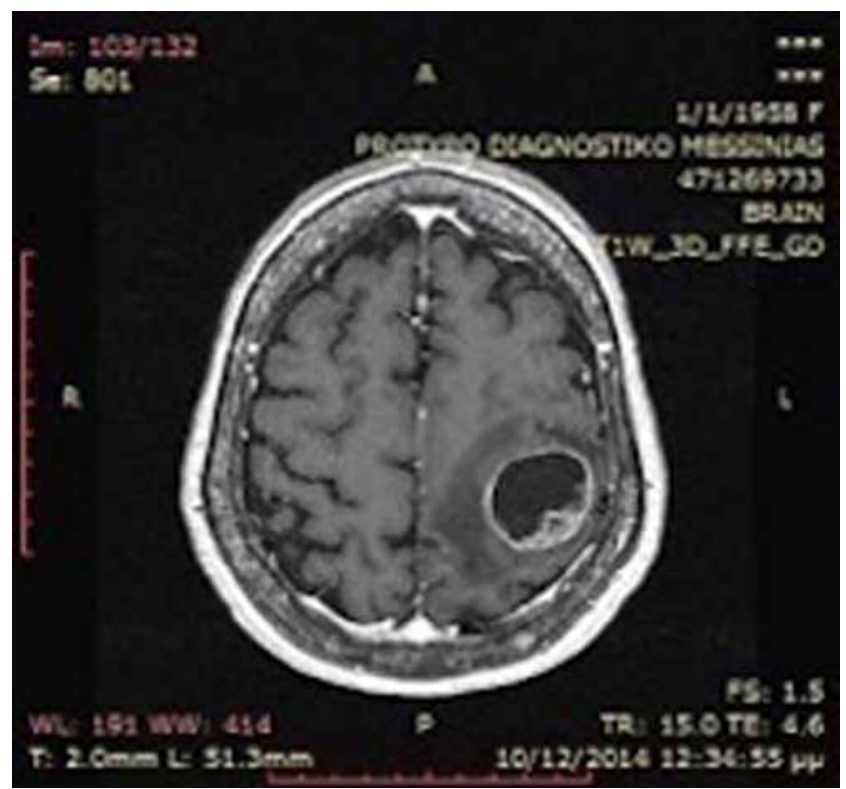

Figure 3

An axial MRI post-contrast TI sequence demonstrating a parietal lobe metastasis from a parathyroid carcinoma.

Published by Bioscientifica Ltd 
carcinoma tumourigenesis (Carpten et al. 2002). Inactivating HRPT2 mutations are frequently revealed in germ line cells of these patients, and are associated with a syndromic form of the disease known as the HJTS (Juhlin et al. 2006).

Parafibromin, the protein product of HRPT2, has also been linked to the Wingless type (Wnt) pathway through its nuclear association with $\beta$-catenin (Mosimann et al. 2006). In the absence of Wnt signalling, $\beta$-catenin is phosphorylated and subsequently degraded by a protein complex consisting of axin, adenomatous polyposis coli (APC) and glycogen synthase kinase 3- $\beta$ (GSK3- $\beta$ ) (Van Noort et al. 2002), which have been associated with parathyroid carcinoma development. In vitro studies have shown a loss of APC and GSK3- $\beta$ immunoreactivity in sporadic parathyroid carcinomas without an increase in $\beta$-catenin or cyclin D1 levels (Juhlin et al. 2009). The normal function of GSK3- $\beta$ would theoretically be in agreement with a tumour suppressor function; however, inactivating alterations of the GSK3- $\beta$ gene have not been reported in human cancers (Karim et al. 2004).

\section{Current treatment}

The treatment of choice for parathyroid carcinoma is surgery. Therapeutic options for non-resectable and metastatic parathyroid carcinoma are limited. The primary aim is to control hypercalcaemia, and although mitramycin, plicamycin, gallium nitrate, bisphosphonates, calcitonin and glucocorticoids have been used, the calcimimetic cinacalcet is the most effective (Wei \& Harari 2012). Locoregional treatments including ethanol ablation, radiofrequency ablation and trans-arterial embolisation present palliative treatment methods (Wei $\&$ Harari 2012). There are also recent reports on the use of frequent denosumab for intractable hypercalcaemia (Karuppiah 2014). Chemotherapy with dacarbazine and several other regimens are mostly ineffective (Wei \& Harari 2012), although radiofrequency ablation of metastatic parathyroid carcinoma may control disease with a survival benefits of up to 15 months (Iguchi et al. 2008, Lourenco et al. 2012). Recent guidelines suggest that adjuvant radiotherapy should be reserved as a palliative option (Wilhelm et al. 2016).

\section{Molecular targeted treatment}

Data are scarce with regard to molecular targeted treatment in these rare neoplasms. Loss of APC expression suggests the possibility for oncological intervention in patients with parathyroid carcinoma as cyclooxygenase-2 (COX-2) inhibitors have been shown to exhibit chemo-preventive features in colorectal cancer (Giardiello et al. 1993, Eisinger et al. 2007). Recently, it has been shown that truncated APC can target $\beta$-catenin for destruction, but only in the absence of COX enzyme activity, providing a possible molecular explanation for the promising results of COX-2 inhibition in colorectal cancer (Eisinger et al. 2007). In vitro, the COX-2 inhibitor NS-398 suppressed parathyroid-related peptide (PTHrP) production in colorectal cancer (Saito et al. 2007). AntiPTH immunotherapy has been described in some case reports, demonstrating biochemical control and clinical improvement as well as reduction of the size of metastases (Betea et al. 2004, Horie et al. 2010). Despite these promising results, such therapy is not easily available.

Type I membrane-bound alpha-Klotho (Klotho) defines tissue specificity for the phosphaturic hormone fibroblast growth factor-23 (FGF23) by acting as a permissive co-receptor (Urakawa et al. 2006). FGF23 binds to binary complexes of an FGF receptor (FGF-R) and Klotho to suppress parathyroid hormone (PTH) secretion (Krajisnik et al. 2007). Klotho activity has also been implicated as fundamental for the stimulation of PTH secretion during hypocalcaemic conditions (Imura et al. 2007), although the underlying mechanism has been challenged (Martuseviciene et al. 2011). An in vitro study has demonstrated that blocking a parathyroid-FGF23 signalling pathway, involving calcineurin, led to abolition ofFGF23-induced suppresion ofPTHsecretion(Olausonetal. 2013). Thus, this pathway could be another future molecular target pathway for the treatment of parathyroid carcinoma.

The epidermal growth factor receptor (EGF-R, ERBB1, HER1) and its ligands have been reported to play an important role in bone biology and in mediating the anabolic actions of intermittent PTH. Amphiregulin (AREG), a ligand of EGF-R, has been identified to be a target gene for PTH in vitro and in vivo (Schneider et al. 2009) mediating the anabolic bone effect of PTH. However, it is still unclear as to whether these putative effects of AREG are an essential component of PTH's anabolic actions on bone (Jay et al. 2015).

In summary, the therapeutic options for unresectable parathyroid carcinoma are limited and largely ineffective. Surgery is the only curative treatment for parathyroid carcinoma. MTTs are relatively under-explored clinically to date, although anti-PTH immunotherapy in some case series seems to show some encouraging results.

Published by Bioscientifica Ltd 
Nevertheless, parathyroid carcinoma may be relatively indolent in terms of progression, and aggressive medical control of the associated hypercalcaemia is an essential part of its management.

\section{Conclusions}

MTT either alone or in combination with standard treatments has shown promising results when current therapies such as surgery, chemotherapy, and/or radiotherapy have failed to treat malignant adrenal, pituitary and parathyroid tumours. For progressive metastatic PCs/PGLs, PRRT (including 131I MIBG) as well as sunitinib have shown preliminary evidence of antitumour activity as either first-line treatment or following progression with currently available treatments, and in combination with TKIs, mTOR inhibitors and other agents. Combination treatment of chemotherapy with TKIs or immunotherapy could be considered in patients with ACCs who have failed standard treatment, albeit with significant adverse events. Malignant and aggressive pituitary adenomas may respond to PRRT either as single agents or in combination with temozolomide. There are as yet limited data on the role of MTT in parathyroid carcinoma. Nevertheless, MTT appears to be the future for the management of these rare malignant endocrine tumours allowing for a more customised and individualised approach to the therapy. Combination strategies targeting more than one signalling pathway are most promising, at least in vitro. Immunotherapy has also yet to be introduced into these therapeutic paradigms. Multicentre trials are needed to obtain robust conclusions and the development of centralised databases accessible to different centres could help to better interrogate these tumours in larger populations.

\section{Declaration of interest}

The authors declare that there is no conflict of interest that could be perceived as prejudicing the impartiality of this review.

\section{Funding}

This work did not receive any specific grant from any funding agency in the public, commercial, or not-for-profit sector.

\section{References}

Arvai K, Nagy K, Barti-Juhasz H, Petak I, Krenács T, Micsik T, Végső G, Perner F \& Szende B 2012 Molecular profiling of parathyroid hyperplasia, adenoma and carcinoma. Pathology and Oncology Research 18 607-614. (doi: 10.1007/s12253-011-9483-7).
Assié G, Letouze E, Fassnacht M, Jouinot A, Luscap W, Barreau O, Omeiri H, Rodriguez S, Perlemoine K, Rene-Corail F, et al. 2014 Integrated genomic characterization of adrenocortical carcinoma. Nature Genetics 46 607-612. (doi:10.1038/ng.2953)

Averbuch SD, Steakley CS, Young RC, Gelmann EP, Goldstein DS, Stull R \& Keiser HR 1988 Malignant pheochromocytoma: effective treatment with a combination of cyclophosphamide, vincristine, and dacarbazine. Annals of Internal Medicine 15 267-273. (doi:10.7326/0003-4819-109-4-267)

Ayala-Ramirez M, Feng L, Johnson MM, Ejaz S, Habra MA, Rich T, Busaidy N, Cote GJ, Perrier N, Phan A, et al. 2011 Clinical risk factors for malignancy and overall survival in patients with pheochromocytomas and sympathetic paragangliomas: primary tumor size and primary tumor location as prognostic indicators. Journal of Clinical Endocrinology and Metabolism 96 717-725. (doi:10.1210/jc.2010-1946)

Ayala-Ramirez M, Chougnet CN, Habra MA, Palmer JL, Leboulleux S, Cabanillas ME, Caramella C, Anderson P, Al Ghuzlan A, Waguespack SG, et al. 2012a Treatment with sunitinib for patients with progressive metastatic pheochromocytomas and sympathetic paragangliomas. Journal of Clinical Endocrinology and Metabolism 97 4040-4050. (doi:10.1210/jc.2012-2356)

Ayala-Ramirez M, Feng L, Habra MA, Rich T, Dickson PV, Perrier N, Phan A, Waguespack S, Patel S \& Jimenez C 2012b Clinical benefits of systemic chemotherapy for patients with metastatic pheochromocytomas or sympathetic extra-adrenal paragangliomas: insights from the largest single-institutional experience. Cancer 118 2804-2812. (doi:10.1002/cncr.26577)

Aung Naing SF, Habra MA, Chugh R, Kebebew E, Russell J, Welshans D, Fassnacht M, Kroiss M, Goebeler ME, Ijzerman M, et al. 2015 ATR101 phase 1 clinical study for adrenocortical carcinoma. Journal of Clinical Oncology 33 (15 suppl) abstract TPS4585. (available at: http://ascopubs.org/doi/abs/10.1200/jco.2015.33.15_suppl.tps4585)

Baldari S, Ferraù F, Alafaci C, Herberg A, Granata F, Militano V, Salpietro FM, Trimarchi F \& Cannavò S 2012 First demonstration of the effectiveness of peptide receptor radionuclide therapy (PRRT) with 8. 11In-DTPA-octreotide in a giant PRL-secreting pituitary adenoma resistant to conventional treatment. Pituitary 15 57-60 (doi:10.1007/ s11102-011-0373-5)

Banerji U 2009 Heat shock protein 90 as a drug target: some like it hot. Clinical Cancer Research 15 9-14. (doi:10.1158/1078-0432.CCR-080132)

Batisse M, Raverot G, Maqdasy S, Durando X, Sturm N, Montoriol PF, Kemeny JL, Chazal J, Trouillas J \& Tauveron I 2013 Aggressive silent GH pituitary tumor resistant to multiple treatments, including temozolomide. Cancer Investigation 31 190-196. (doi:10.3109/073579 07.2013.775293)

Berruti A, Sperone P, Ferrero A, Germano A, Ardito A, Priola AM, De Francia S, Volante M, Daffara F, Generali D, et al. 2012a Phase II study of weekly paclitaxel and sorafenib as second/third-line therapy in patients with adrenocortical carcinoma. European Journal of Endocrinology 166 451-458. (doi:10.1530/EJE-11-0918)

Berruti A, Baudin E, Gelderblom H, Haak R, Porpiglia F, Fassnacht M \& $G$ Pentheroudakis, on behalf of the ESMO guidelines working group $2012 b$ Adrenal cancer: ESMO clinical practice guidelines for diagnosis, treatment and follow-up. Annals of Oncology $\mathbf{2 3}$ (Supplement 7) 131-138. (doi:10.1093/annonc/mds231)

Betea D, Bradwell AR, Harvey TC, Mead GP, Schmidt-Gayk H, Ghaye B, Daly AF \& Beckers A 2004 Hormonal and biochemical normalization and tumor shrinkage induced by anti-parathyroid hormone immunotherapy in a patient with metastatic parathyroid carcinoma. Journal of Clinical Endocrinology and Metabolism 89 3413-3420. (doi:10.1210/jc.2003-031911)

Bode H, Seiz M, Lammert A, Brockmann MA, Back W, Hammes HP \& Thome C 2010 SOM230 (pasireotide) and temozolomide achieve sustained control of tumour progression and ACTH secretion in 
pituitary carcinoma with widespread metastases. Experimental and Clinical Endocrinology and Diabetes 118 760-763.

(doi:10.1055/s-0030-1253419)

Brave SR, Odedra R, James NH, Smith NR, Marshall GB, Acheson KL, Baker D, Howard Z, Jackson L, Ratcliffe K, et al. 2011 Vandetanib inhibits both VEGFR-2 and EGFR signalling at clinically relevant drug levels in preclinical models of human cancer. International Journal of Oncology 39 271-278. (doi:10.3892/ijo.2011.1022)

Brito LP, Ribeiro TC, Almeida MQ, Jorge AA, Soares IC, Latronico AC, Mendonca BB, Fragoso MC \& Lerario AM 2012 The role of fibroblast growth factor receptor 4 overexpression and gene amplification as prognostic markers in pediatric and adult adrenocortical tumors. Endocrine-Related Cancer 19 11-13. (doi:10.1530/ERC-11-0231)

Bush ZM, Longtine JA, Cunningham T, Schiff D, Jane JA Jr, Vance ML, Thorner MO, Laws ER Jr \& Lopes MB 2010 Temozolomide treatment for aggressive pituitary tumors: correlation of clinical outcome with $\mathrm{O}(6)$-methylguanine methyltransferase (MGMT) promoter methylation and expression. Journal of Clinical Endocrinology and Metabolism 95 280-290. (doi:10.1210/jc.2010-0441)

Bussey KJ, Bapat A, Linnehan C, Wandoloski M, Dastrup E, Rogers E, Gonzales P \& Demeure MJ 2016 Targeting polo-like kinase 1, a regulator of p53, in the treatment of adrenocortical carcinoma. Clinical and Translation Medicine 5 1. (doi:10.1186/s40169-015-0080-3)

Cakir M \& Grossman AB 2009 Targeting MAPK(Ras/ERK) and PI3K/Akt pathways in pituitary tumorigenesis. Expert Opinion on Therapeutic Targets 13 1121-1134. (doi:10.1517/14728220903170675)

Carpten JD, Robbins CM, Villablanca A, Forsberg L, Presciuttini S, Bailey-Wilson J, Simonds WF, Gillanders EM, Kennedy AM, Chen JD, et al. 2002 HRPT2, encoding parafibromin, is mutated in hyperparathyroidism jaw tumor syndrome. Nature Genetics $\mathbf{3 2}$ 676-680. (doi:10.1038/ng1048)

Cassol CA, Winer D, Liu W, Guo M, Ezzat S \& Asa SL 2014 Tyrosine kinase receptors as molecular targets in pheochromocytomas and paragangliomas. Modern Pathology 27 1050-1062 (doi:10.1038/ modpathol.2013.233)

Cerovac V, Monteserin-Garcia J, Rubinfeld H, Buchfelder M, Losa M, Florio T, Paez-Pereda M, Stalla GK \& Theodoropoulou M 2010 The somatostatin analogue octreotide confers sensitivity to rapamycin treatment on pituitary tumor cells. Cancer Research 70 666-674. (doi:10.1158/0008-5472.CAN-09-2951)

Chatzellis E, Alexandraki K, Androulakis II \& Kaltsas G 2015 Aggressive pituitary tumors. Neuroendocrinology 101 87-104. (doi:10.1159/000371806)

Chen W, Hill H, Christie A, Kim MS, Holloman E, Pavia-Jimenez A, Homayoun F, Ma Y, Patel N, Yell P, et al. 2016 Targeting renal cell carcinoma with a HIF-2 antagonist. Nature 539 112-117. (doi:10.1038/nature19796)

Cho H, Du X, Rizzi JP, Liberzon E, Chakraborty AA, Gao W, Carvo I, Signoretti S, Bruick RK, Josey JA, et al. 2016 On-target efficacy of a HIF- $2 \alpha$ antagonist in preclinical kidney cancer models. Nature 539 107-111. (doi:10.1038/nature19795)

Colao A, Bronstein MD, Freda P, Gu F, Shen CC, Gadelha M, Fleseriu M, van der Lely AJ, Farrall AJ \& Hermosillo Reséndiz K 2014 Pasireotide C2305 Study Group. Pasireotide versus octreotide in acromegaly: a head-to-head superiority study. Journal of Clinical Endocrinology and Metabolism 99 791-799. (doi:10.1210/jc.2013-2480)

Cooper O, Vlotides G, Fukuoka H, Greene MI \& Melmed S 2011 Expression and function of ErbB receptors and ligands in the pituitary. Endocrine-Related Cancer 18 197-211. (doi:10.1530/ERC-11-0066)

Creemers SG, Hofland LJ, Korpershoek E, Franssen GJ, van Kemenade FJ, de Herder WW \& Feelders RA 2016 Future directions in the diagnosis and medical treatment of adrenocortical carcinoma. Endocrine-Related Cancer 23 43-69. (doi:10.1530/erc-15-0452)

Dahia PL, Ross KN, Wright ME, Hayashida CY, Santagata S, Barontini M, Kung AL, Sanso G, Powers JF, Tischler AS, et al. 2005 A HIF1alpha regulatory loop links hypoxia and mitochondrial signals in pheochromocytomas. PLoS Genetics 1 72-80. (doi:10.1371/journal. pgen.0010008)

Dahia PL 2014 Pheochromocytoma and paraganglioma pathogenesis: learning from genetic heterogeneity. Nature Reviews Cancer 14 108-119. (doi:10.1038/nrc3648)

de Joussineau C, Sahut-Barnola I, Levy I, Saloustros E, Val P, Stratakis CA \& Martinez A 2012 The cAMP pathway and the control of adrenocortical development and growth. Molecular and Cellular Endocrinology 351 28-36. (doi:10.1016/j.mce.2011.10.006)

De Martino MC, Feelders RA, de Herder WW, van Koetsveld PM, Dogan F, Janssen JA, Waaijers AM, Pivonello C, Lamberts SW, Colao A, et al. 2014 Characterization of the mTOR pathway in human normal adrenal and adrenocortical tumors. Endocrine-Related Cancer 21 601-613. (doi:10.1530/ERC-13-0112)

De Martino MC, van Koetsveld PM, Feelders RA, Lamberts SW, de Herder WW, Colao A, Pivonello R \& HoflandLJ 2016 Effects of combination treatment with sirolimus and mitotane on growth of human adrenocortical carcinoma cells. Endocrine 52 664-677. (doi:10.1007/s12020-015-0818-0)

Del Basso De Caro M, Solari D, Pagliuca F, Villa A, Guadagno E, Cavallo LM, Colao A, Pettinato G \& Cappabianca P 2016 Atypical pituitary adenomas: clinical characteristics and role of ki-67 and p53 in prognostic and therapeutic evaluation. A series of 50 patients. Neurosurgical Review 40 105-114. (doi:10.1007/s10143016-0740-9)

Doghman M, Karpova T, Rodrigues GA, Arhatte M, De Moura J, Cavalli LR, Virolle V, Barbry P, Zambetti GP, Figueiredo BC, et al. 2007 Increased steroidogenic factor-1 dosage triggers adrenocortical cell proliferation and cancer. Molecular Endocrinology 21 2968-2987. (doi:10.1210/me.2007-0120)

Doghman M, Cazareth J, Douguet D, Madoux F, Hodder P \& Lalli E 2009 Inhibition of adrenocortical carcinoma cell proliferation by steroidogenic factor-1 inverse agonists. Journal of Clinical Endocrinology and Metabolism 94 2178-2183. (doi:10.1210/jc.2008-2163)

Doghman M, El Wakil A, Cardinaud B, Thomas E, Wang J, Zhao W, PeraltaDel Valle MH, Figueiredo BC, Zambetti GP \& Lalli E 2010 Regulation of insulin-like growth factor-mammalian target of rapamycin signaling by microRNA in childhood adrenocortical tumors. Cancer Research 70 4666-4675. (doi:10.1158/0008-5472.CAN-09-3970)

Duregon E, Volante M, Giorcelli J, Terzolo M, Lalli E \& Papotti M 2013 Diagnostic and prognostic role of steroidogenic factor 1 in adrenocortical carcinoma: a validation study focusing on clinical and pathologic correlates. Human Pathology 44 822-828. (doi:10.1016/j.humpath.2012.07.025)

Druce MR, Kaltsas GA, Fraenkel M, Gross DJ \& Grossman AB 2009 Novel and evolving therapies in the treatment of malignant phaeochromocytoma: experience with the mTOR inhibitor everolimus (RAD001). Hormone and Metabolic Research 41 697-702. (doi: 10.1055/s-0029-1220687).

Dworakowska D \& Grossman AB 2012 The molecular pathogenesis of corticotroph tumours. European Journal of Clinical Investigation 42 665-676. (doi:10.1111/j.1365-2362.2011.02621.x)

Eisinger AL, Nadauld LD, Shelton DN, Prescott SM, Stafforini DM \& Jones DA 2007 Retinoic acid inhibits $\beta$-catenin through suppression of cox-2: a role for truncated adenomatous polyposis coli. Journal of Biological Chemistry 282 29394-29400. (doi:10.1074/jbc. M609768200)

Elshafie O, Al Badaai Y, Alwahaibi K, Qureshi A, Hussein S, Al Azzri F, Almamari A \& Woodhouse N 2014 Catecholamine-secreting carotid body paraganglioma: successful preoperative control of hypertension and clinical symptoms using high-dose long-acting octreotide. Endocrinology, Diabetes and Metabolism Case Reports 2014140051. (doi:10.1530/edm-14-0051)

Elston MS, Meyer-Rochow GY, Conaglen HM, Clarkson A, Clifton-Bligh RJ, Conaglen JV \& Gill AJ 2015 Increased SSTR2A and SSTR3 
expression in succinate dehydrogenase-deficient pheochromocytomas and paragangliomas. Human Pathology 46 390-396. (doi:10.1016/j.humpath.2014.11.012)

Ezzat S, Asa SL, Couldwell WT, Barr CE, Dodge WE, Vance ML \& McCutcheon IE 2004 The prevalence of pituitary adenomas: a systematic review. Cancer 101 613-619. (doi:10.1002/cncr.20412)

Farrell WE \& Clayton RN 2003 Epigenetic change in pituitary tumorigenesis. Endocrine-Related Cancer 10 323-330. (doi:10.1677/ erc.0.0100323)

Fassnacht M, Terzolo M, Allolio B, Baudin E, Haak H, Berruti A, Welin S, Schade-Brittinger C, Lacroix A, Jarzab B, et al. 2012 Combination chemotherapy in advanced adrenocortical carcinoma. New England Journal of Medicine 366 2189-2197. (doi:10.1056/NEJMoa1200966)

Fassnacht M, Berruti A, Baudin E, Demeure MJ, Gilbert J, Haak H, Kroiss M, Quinn DI, Hesseltine E, Ronchi CL, et al. 2015 Linsitinib (OSI-906) versus placebo for patients with locally advanced or metastatic adrenocortical carcinoma: a double-blind, randomised, phase 3 study. Lancet Oncology 16 426-435. (doi:10.1016/S1470-2045(15)70081-1)

Fassnacht M, Arlt W, Bancos I, Dralle H, Newell-Price J, Sahdev A, Tabarin A, Terzolo M, Tsagarakis S \& Dekkers OM 2016 Management of adrenal incidentalomas: European society of endocrinology clinical practice guideline in collaboration with the European network for the study of adrenal tumors. European Journal of Endocrinology 175 1-34. (doi:10.1530/EJE-16-0467)

Favier J, Amar L \& Gimenez-Roqueplo AP 2015 Paraganglioma and phaeochromocytoma: from genetics to personalized medicine. Nature Reviews Endocrinology 11 101-111. (doi:10.1038/nrendo.2014.188)

Finn RS, Miguel M, Hope RS, Jones S, Im S, Gelmon K, Harbeck N, Lipatov ON, Walshe JM, Moulder S, et al. 2016 Palbociclib and letrozole in advanced breast cancer. New England Journal of Medicine 375 1925-1936 (doi:10.1056/NEJMoa1607303)

Fliedner SM, Engel T, Lendvai NK, Shankavaram U, Nölting S, Wesley R, Elkahloun AG, Ungefroren H, Oldoerp A, Lampert G, et al. 2014 Anticancer potential of MAPK pathway inhibition in paragangliomaseffect of different statins on mouse pheochromocytoma cells. PLoS ONE 9 e97712. (doi:10.1371/journal.pone.0097712)

Fraenkel M, Gueorguiev M, Barak D, Salmon A, Grossman AB \& Gross DJ 2013 Everolimus therapy for progressive adrenocortical cancer. Endocrine 44 187-192. (doi:10.1007/s12020-013-9878-1)

Fukuoka H, Cooper O, Ben-Shlomo A, Mamelak A, Ren SG, Bruyette D \& Melmed S 2011 EGFR as a therapeutic target for human, canine, and mouse ACTH-secreting pituitary adenomas. Journal of Clinical Investigation 121 4712-4721. (doi:10.1172/JCI60417)

Gagliano T, Gentilin E, Tagliati F, Benfini K, Di Pasquale C, Feo C, Falletta S, Riva E, Degli Uberti E \& Zatelli MC 2015 Inhibition of epithelial growth factor receptor can play an important role in reducing cell growth and survival in adrenocortical tumors. Biochemical Pharmacology 98 639-648. (doi:10.1016/j. bcp.2015.10.012)

Giardiello FM, Hamilton SR, Krush AJ, Booker S, Jen J, Giardiello FM, Hamilton SR, Vogelstein B \& Kinzler KW 1993 Treatment of colonic and rectal adenomas with sulindac in familial adenomatous polyposis. New England Journal of Medicine 328 1313-1316. (doi:10.1056/NEJM199305063281805)

Giubellino A, Bullova P, Nölting S, Turkova H, Powers JF, Liu Q, Guichard S, Tischler AS, Grossman AB \& Pacak K 2013a Combined inhibition of mTORC1 and mTORC2 signaling pathways is a promising therapeutic option in inhibiting pheochromocytoma tumor growth: in vitro and in vivo studies in female athymic nude mice. Endocrinology 154 646-652. (doi:10.1210/en.2012-1854)

Giubellino A, Sourbier C, Lee MJ, Scroggins B, Bullova P, Landau M, Ying W, Neckers L, Trepel JB \& Pacak K 2013b Targeting heat shock protein 90 for the treatment of malignant pheochromocytoma. PLoS ONE 8 e56083. (doi:10.1371/journal.pone.0056083)

Givi B, Shah JP 2010 Parathyroid carcinoma. Clinical Oncology 22 498-507. (doi:10.1016/j.clon.2010.04.007)
Gonias S, Goldsby R, Matthay KK, Hawkins R, Price D, Huberty J, Damon L, Linker C, Sznewajs A, Shiboski S, et al. 2009 Phase II study of high-dose [131I]metaiodobenzylguanidine therapy for patients with metastatic pheochromocytoma and paraganglioma. Journal of Clinical Oncology 27 4162-4168. (doi:10.1200/ JCO.2008.21.3496)

Greenman Y, Cooper O, Yaish I, Robenshtok E, Sagiv N, Jonas-Kimchi T, Yuan X, Gertych A, Shimon I, Ram Z, et al. 2016 Treatment of clinically nonfunctioning pituitary adenomas with dopamine agonists. European Journal of Endocrinology 175 63-72. (doi:10.1530/EJE-16-0206)

Gross DJ, Munter G, Bitan M, Siegal T, Gabizon A, Weitzen R, Merimsky O, Ackerstein A, Salmon A, Sella A, et al. 2006 The role of imatinib mesylate (Glivec) for treatment of patients with malignant endocrine tumors positive for c-kit or PDGF-R. Endocrine-Related Cancer 13 535-540. (doi:10.1677/erc.1.01124)

Hadoux J, Favier J, Scoazec JY, Leboulleux S, Al Ghuzlan A, Caramella C, Déandreis D, Borget I, Loriot C, Chougnet C, et al. 2014 SDHB mutations are associated with response to temozolomide in patients with metastatic pheochromocytoma or paraganglioma. International Journal of Cancer 135 2711-2720 (doi:10.1002/ijc.28913)

Hahn NM, Reckova M, Cheng L, Baldridge LA, Cummings OW \& Sweeney CJ 2009 Patient with malignant paraganglioma responding to the multikinase inhibitor sunitinib malate. Journal of Clinical Oncology 27 460-463. (doi:10.1200/JCO.2008.19.9380)

Halperin DM, Phan AT, Hoff AO, Aaron M, Yao JC \& Hoff PM 2014 A phase I study of imatinib, dacarbazine, and capecitabine in advanced endocrine cancers. BMC Cancer 14 561. (doi:10.1186/1471-2407-14-561)

Haluska P, Worden F, Olmos D, Yin D, Schteingart D, Batzel GN, Paccagnella ML, de Bono JS, Gualberto A \& Hammer GD 2010 Safety, tolerability, and pharmacokinetics of the anti-IGF-1R monoclonal antibody figitumumab in patients with refractory adrenocortical carcinoma. Cancer Chemotherapy and Pharmacology 65 765-773. (doi:10.1007/s00280-009-1083-9)

Hamill J, Maoate K, Beasley SW, Corbett R \& Evans J 2002 Familial parathyroid carcinoma in a child. Journal of Paediatrics and Child Health 8 314-317. (doi:10.1046/j.1440-1754.2002.00802.x)

Hay N \& Sonenberg N 2004 Upstream and downstream of mTOR. Genes and Development 18 1926-1945. (doi:10.1101/gad.1212704)

Haugen BR, Alexander EK, Bible KC, Doherty GM, Mandel SJ, Nikiforov YE, Pacini F, Randolph GW, Sawka AM, Schlumberger M, et al. 2016 American thyroid association management guidelines for adult patients with thyroid nodules and differentiated thyroid cancer: the American thyroid association guidelines task force on thyroid nodules and differentiated thyroid cancer. Thyroid 26 1-133. (doi: 10.1089/thy.2015.0020).

Heaney A 2011 Clinical review: pituitary carcinoma: difficult diagnosis and treatment. Journal of Clinical Endocrinology and Metabolism 96 3649-3660. (doi:10.1210/jc.2011-2031)

Horie I, Ando T, Inokuchi N, Mihara Y, Miura S, Imaizumi M, Usa T, Kinoshita N, Sekine I, Kamihara S, et al. 2010 First Japanese patient treated with parathyroid hormone peptide immunization for refractory hypercalcemia caused by metastatic parathyroid carcinoma. Endocrine Journal 57 287-292. (doi:10.1507/endocrj.K09E283)

Huang J, Sun C, Zhang T, Pan L, Wang S, He Q \& Li D 2014 Potent antitumor activity of HSP90 inhibitor AUY922 in adrenocortical carcinoma. Tumour Biology 35 8193-8199. (doi:10.1007/s13277014-2063-1)

Iguchi T, Yasui K, Hiraki T, Gobara H, Mimura H, Sato S, Fujiwara H, Yano A, Doihara H \& Kanazawa S 2008 Radiofrequency ablation of functioning lung metastases from parathyroid carcinoma. Journal of Vascular and Interventional Radiology 19 462-464. (doi:10.1016/j. jvir.2007.12.440)

Jain M, Zhang LS, He M, Zhang YQ, Shen M \& Kebebew E 2013 TOP2A is overexpressed and is a therapeutic target for adrenocortical carcinoma. Endocrine-Related Cancer 20 361-370. (doi:10.1530/ERC-12-0403) 
Jay FF, Vaidya M, Porada SM, Andrukhova O, Schneider MR \& Erben RG 2015 Amphiregulin lacks an essential role for the bone anabolic action of parathyroid hormone. Molecular and Cellular Endocrinology 417 158-165. (doi:10.1016/j.mce.2015.09.031)

Jesús García-Donas SHP, Guix M, Duran MAC, Méndez- Vidal MJ, Jiménez-Fonseca P, Laínez N, Mateos LL, Moreno F, Gonzalez ERS, Duran I, et al. 2014 Phase II study of dovitinib in first line metastatic or (non resectable primary) adrenocortical carcinoma (ACC): SOGUG study 2011-03. Journal of Clinical Oncology 32 (5 Suppl) abstract 4588.

Jiang Z, Gui S \& Zhang Y 2012 Analysis of differential gene expression in plurihormonal pituitary adenomas using bead-based fiber-optic arrays. Journal of Neurooncology 108 341-348. (doi:10.1007/s11060011-0792-1)

Jimenez C, Cabanillas ME, Santarpia L, Jonasch E, Kyle KL, Lano EA, Matin SF, Nunez RF, Perrier ND, Phan A, et al. 2009 Use of the tyrosine kinase inhibitor sunitinib in a patient with von HippelLindau disease: targeting angiogenic factors in pheochromocytoma and other von Hippel-Lindau disease-related tumors. Journal of Clinical Endocrinology and Metabolism 94 386-391. (doi:10.1210/jc.2008-1972)

Jochmanová I, Yang C, Zhuang Z \& Pacak K 2013 Hypoxia-inducible factor signaling in pheochromocytoma: turning the rudder in the right direction. Journal of National Cancer Institute 105 1270-1283. (doi:10.1093/jnci/djt201)

Jones RL, Kim ES, Nava-Parada P, Alam S, Johnson FM, Stephens AW, Simantov R, Poondru S, Gedrich R, Lippman SM, et al. 2015 Phase I study of intermittent oral dosing of the insulin-like growth factor-1 and insulin receptors inhibitor OSI-906 in patients with advanced solid tumors. Clinical Cancer Research 21 693-700. (doi:10.1158/1078-0432.CCR-14-0265)

Jouanneau E, Wierinckx A, Ducray F, Favrel V, Borson-Chazot F, Honnorat J, Trouillas J \& Raverot G 2012 New targeted therapies in pituitary carcinoma resistant to temozolomide. Pituitary 15 37-43. (doi:10.1007/s11102-011-0341-0)

Juhlin C, Larsson C, Yakoleva T, Leibiger I, Leibiger B, Alimov A, Weber G, Höög A \& Villablanca A 2006 Loss of parafibromin expression in a subset of parathyroid adenomas. Endocrine-Related Cancer 13 509-523. (doi:10.1677/erc.1.01058)

Juhlin CC, Haglund F, Villablanca A, Forsberg L, Sandelin K, Bränström R, Larsson C \& Höög A 2009 Loss of expression for the Wnt pathway components adenomatous polyposis coli and glycogen synthase kinase 3-beta in parathyroid carcinomas. International Journal of Oncology 34 481-492. (doi:10.3892/ijo_00000173)

Imura A, Tsuji Y, Murata M, Maeda R, Kubota K, Iwano A, Obuse C, Togashi K, Tominaga M \& Kita N 2007 Alpha-Klotho as a regulator of calcium homeostasis. Science 316 1615-1618. (doi:10.1126/ science.1135901)

Kaltsas GA, Nomikos P, Kontogeorgos G, Buchfelder M \& Grossman AB $2005 a$ Clinical review: diagnosis and management of pituitary carcinomas. Journal of Clinical Endocrinology and Metabolism 90 3089-3099. (doi:10.1210/jc.2004-2231)

Kaltsas GA, Papadogias D, Makras P \& Grossman AB 2005 $b$ Treatment of advanced neuroendocrine tumours with radiolabelled somatostatin analogues. Endocrine-Related Cancer 12 683-699. (doi:10.1677/ erc.1.01116)

Kantorovich V, Koch CA \& Pacak K 2015 Pheochromocytoma and paraganglioma. In Endotext. Eds: De Groot LJ, Chrousos G, Dungan K, et al. South Dartmouth, MA, USA: MDText.com, Inc. (available at: https://www.ncbi.nlm.nih.gov/books/NBK279138/)

Karim R, Tse G, Putti T, Scolyer R \& Lee S 2004 The significance of the Wnt pathway in the pathology of human cancers. Pathology 36 120-128. (doi:10.1080/00313020410001671957)

Karuppiah D, Thanabalasingham G, Shine B, Sadler G, Karavitaki N \& Grossman AB 2014 Refractory hypercalcaemia secondary to parathyroid carcinoma: response to high-dose denosumab. European Journal of Endocrinology 171 K1-K5. (doi:10.1530/EJE-14-0166)

Keblad S, Sundin A, Janson ET, Welin S, Granberg D, Kindmark H, Dunder K, Kozlovacki G, Orlefors H, Sigurd M, et al. 2007
Temozolomide as monotherapy is effective in treatment of advanced malignant neuroendocrine tumors. Clinical Cancer Research $\mathbf{1 3}$ 2986-2991. (doi:10.1158/1078-0432.CCR-06-2053)

Kiessling MK, Curioni-Fontecedro A, Samaras P, Lang S, Scharl M, Aguzzi A, Oldrige DA, Maris JM \& Rogler G 2016 Targeting the mTOR complex by everolimus in NRAS mutant neuroblastoma. PLOS ONE 11 e0147682. doi:10.1371/journal.pone.0147682

Kim JS, Lee YS, Jung MJ \& Hong YK 2016 The predictive value of pathologic features in pituitary adenoma and correlation with pituitary adenoma recurrence. Journal of Pathology and Translational Medicine 50 419-425. (doi:10.4132/jptm.2016.06.30)

Komor J, Reubi JC \& Christ ER 2014 Peptide receptor radionuclide therapy in a patient with disabling non-functioning pituitary adenoma. Pituitary 17 227-231. (doi:10.1007/s11102-013-0494-0)

Krajisnik T, Björklund P, Marsell R, Ljunggren O, Akerström G, Jonsson KB, Westin G \& Larsson TE 2007 Fibroblast growth factor-23 regulates parathyroid hormone and 1alphahydroxylase expression in cultured bovine parathyroid cells. Journal of Endocrinology 195 125-131. (doi:10.1677/JOE-07-0267)

Kroiss M, Quinkler M, Johanssen S, van Erp NP, Lankheet N, Pollinger A, Laubner K, Strasburger CJ, Hahner S, Muller HH, et al. 2012 Sunitinib in refractory adrenocortical carcinoma: a phase II, singlearm, open-label trial. Journal of Clinical Endocrinology and Metabolism 97 3495-3503. (doi:10.1210/jc.2012-1419)

Kulke MH, Stuart K, Enzinger PC, Ryan DP, Clark JW, Muzikansky A, Vincitore M, Michelini A \& Fuchs CS 2006 Phase II study of temozolomide and thalidomide in patients with metastatic neuroendocrine tumors. Journal of Clinical Oncology 24 401-406. (doi:10.1200/JCO.2005.03.6046)

Laurell C, Velazquez-Fernandez D, Lindsten K, Juhlin C, Enberg U, Geli J, Hoog A, Kjellman M, Lundebergm J, Hamberger B, et al. 2009 Transcriptional profiling enables molecular classification of adrenocortical tumours. European Journal of Endocrinology $16 \mathbf{1}$ 141-152. (doi:10.1530/EJE-09-0068)

Lenders JW, Eisenhofer G, Mannelli M \& Pacak K 2005 Phaeochromocytoma. Lancet 366 665-675. (doi:10.1016/S01406736(05)67139-5)

Lenders JW, Duh QY, Eisenhofer G, Gimenez-Roqueplo AP, Grebe SK, Murad MH, Naruse M, Pacak K \& Young WF 2014

Pheochromocytoma and paraganglioma: an endocrine society clinical practice guideline. Journal of Clinical Endocrinology and Metabolism 99 1915-1942. (doi:10.1210/jc.2014-1498)

Lerario AM, Worden FP, Ramm CA, Hesseltine EA, Stadler WM, Else T, Shah MH, Agamah E, Rao K \& Hammer GD 2014 The combination of insulin-like growth factor receptor 1 (IGF1R) antibody cixutumumab and mitotane as a first-line therapy for patients with recurrent/ metastatic adrenocortical carcinoma: a multi-institutional NCI-sponsored trial. Hormones and Cancer 5 232-239. (doi:10.1007/ s12672-014-0182-1)

Libè R, Groussin L, Tissier F, Elie C, René-Corail F, Fratticci A, Jullian E, Beck-Peccoz P, Bertagna X, Gicquel C, et al. 2007 Somatic TP53 mutations are relatively rare among adrenocortical cancers with the frequent 17p13 loss of heterozygosity. Clinical Cancer Research 13 844-850. (doi: 10.1158/1078-0432.ccr-06-2085).

Lin CI, Whang EE, Moalem J \& Ruan DT 2012 Strategic combination therapy overcomes tyrosine kinase coactivation in adrenocortical carcinoma. Surgery 152 1045-1050. (doi: 10.1016/j.surg.2012.08.035).

Liu P, Cheng H, Roberts TM \& Zhao JJ 2009 Targeting the phosphoinositide 3-kinase pathway in cancer. Nature Reviews Drug Discovery 8 627-644. (doi:10.1038/nrd2926)

Liu-Chittenden Y, Jain M, Kumar P, Patel D, Aufforth R, Neychev V, Sadowski S, Gara SK, Joshi BH, Cottle-Delisle C, et al. 2015 Phase I trial of systemic intravenous infusion of interleukin-13-pseudomonas exotoxin in patients with metastatic adrenocortical carcinoma. Cancer Medicine 4 1060-1068. (doi:10.1002/cam4.449)

Losa M, Mazza E, Terreni MR, McCormack A, Gill AJ, Motta M, Cangi MG, Talarico A, Mortini P \& Reni M 2010 Salvage therapy with 
temozolomide in patients with aggressive or metastatic pituitary adenomas: experience in six cases. European Journal of Endocrinology 163 843-851. (doi:10.1530/EJE-10-0629)

Lourenco Jr DE, Hoff AO, Alcantara AEE, Martins RM, Correa PHS \& Menezes M 2012 Radiofrequency ablation of pulmonary metastases in parathyroid carcinoma: an alternative therapy for severe refractory hypercalcemia. Presentation OR27-5. Presented at The Endocrine Society's 94th Annual Meeting and Expo, June 23-26, 2012, Houston, TX. Washington DC, USA: Endocrine Society. (available at: http://press.endocrine.org/doi/abs/10.1210/endomeetings.2012.BCHVD.7.OR27-5)

Ma ZY, Song ZJ, Chen JH, Wang YF, Li SQ, Zhou LF, Mao Y, Li YM, Hu RG, Zhang ZY, et al. 2015 Recurrent gain-of-function USP8 mutations in Cushing's disease. Cell Research 25 306-317 (doi:10.1038/cr.2015.20)

Maclean J, Aldridge M, Bomanji J, Short S \& Fersht N 2014 Peptide receptor radionuclide therapy for aggressive atypical pituitary adenoma/carcinoma: variable clinical response in preliminary evaluation. Pituitary 17 530-538. (doi:10.1007/s11102-013-0540-y)

Mariniello B, Rosato A, Zuccolotto G, Rubin B, Cicala MV, Finco I, Iacobone M, Frigo AC, Fassina A, Pezzani R, et al. 2012 Combination of sorafenib and everolimus impacts therapeutically on adrenocortical tumor models. Endocrine-Related Cancer 19 527-539. (doi:10.1530/ERC-11-0337)

Martiniova L, Lu J, Chiang J, Bernardo M, Lonser R, Zhuang Z \& Pacak K 2011 Pharmacologic modulation of serine/threonine phosphorylation highly sensitizes PHEO in a MPC cell and mouse model to conventional chemotherapy. PLOS ONE 64678. (doi:10.1371/journal.pone.0014678)

Martuseviciene G, Hofman-Bang J, Clausen T, Olgaard K \& Lewin E 2011 The secretory response of parathyroid hormone to acute hypocalcemia in vivo is independent of parathyroid glandular sodium/potassium-ATPase activity. Kidney International 79 742-748. (doi:10.1038/ki.2010.501)

McClenaghan F \& Qureshi YA 2015 Parathyroid cancer. Gland Surgery 4 329-338. (doi:10.1007/978-1-4419-5550-0_8)

McCormack AI, McDonald KL, Gill AJ, Clark SJ, Burt MG, Campbell KA Braund WJ, Little NS, Cook RJ, Grossman AB, et al. 2009 Low O6-methylguanine-DNA methyltransferase (MGMT) expression and response to temozolomide in aggressive pituitary tumours. Clinical Endocrinology 71 226-233. (doi:10.1111/j.1365-2265.2008.03487.x)

McCormack AI, Wass JA \& Grossman AB 2011 Aggressive pituitary tumours: the role of temozolomide and the assessment of MGMT status. European Journal of Clinical Investigation 41 1133-1148. (doi: 10.1111/j.1365-2362.2011).

McCubrey JA, Steelman LS, Chappell WH, Abrams SL, Wong EW, Chang F, Lehmann B, Terrian DM, Milella M, Tafuri A, et al. 2007 Roles of the Raf/ MEK/ERK pathway in cell growth, malignant transformation and drug resistance. Biochimica et Biophysica Acta 1773 1263-1284 (doi:10.1016/j.bbamcr.2006.10.001)

McNeil AR, Blok BH, Koelmeyer TD, Burke MP \& Hilton JM 2000 Phaeochromocytomas discovered during coronial autopsies in Sydney, Melbourne and Auckland. Australian and New Zealand Journal of Medicine 30 648-652. (doi:10.1111/j.1445-5994.2000. tb04358.x)

Melmed S 2003 Mechanisms for pituitary tumorigenesis: the plastic pituitary. Journal of Clinical Investigation 112 1603-1618. (doi:10.1172/JCI20401)

Mohammed AA, El-Shentenawy AM, Sherisher MA \& El-Khatib HM 2014 Target therapy in metastatic pheochromocytoma: current perspectives and controversies. Oncology Reviews 8 249. (doi:10.4081/ oncol.2014.249)

Mizuno E, Iura T, Mukai A, Yoshimori T, Kitamura N \& Komada M 2005 Regulation of epidermal growth factor receptor down-regulation by UBPY-mediated deubiquitination at endosomes. Molecular Biology of the Cell 16 5163-5174. (doi:10.1091/mbc.E05-06-0560)
Mohebati A, Shaha A \& Shah J 2012 Parathyroid carcinoma: challenges in diagnosis and treatment. Hematology/Oncology Clinics of North America 26 1221-1238. (doi:10.1016/j.hoc.2012.08.009)

Mosimann C, Hausmann G \& Basler K 2006 Parafibromin/Hyrax activates Wnt/Wg target gene transcription by direct association with $\beta$-catenin/Armadillo. Cell 125 327-341. (doi:10.1016/j. cell.2006.01.053)

Mukherjee JJ, Kaltsas GA, Islam N, Plowman PN, Foley R, Hikmat J, Britton KE, Jenkins PJ, Chew SL, Monson JP, et al. 2001 Treatment of metastatic carcinoid tumours, phaeochromocytoma, paraganglioma and medullary carcinoma of the thyroid with (131) I-metaiodobenzylguanidine [(131)I-mIBG]. Clinical Endocrinology 55 47-60. (doi:10.1046/j.1365-2265.2001.01309.x)

Murthy S, Pacak K \& Loh Y 2010 Carboxypeptidase E: elevated expression correlated with tumor growth and metastasis in pheochromocytomas and other cancers. Cellular and Molecular Neurobiology 30 1377-1381. (doi:10.1007/s10571-010-9592-y)

Muşat M, Korbonits M, Kola B, Borboli B, Hanson R, Nanzer M, Grigson J, Jordan S, Morris G, Gueorguiev M, et al. 2005 Enhanced protein kinase B/Akt signaling in pituitary tumours. Endocrine-Related Cancer 12 423-433. (doi:10.1677/erc.1.00949)

Muşat M, Morris DG, Korbonits M \& Grossman AB 2010 Cyclins and their related proteins in pituitary tumourigenesis. Molecular and Cellular Endocrinology 326 25-29. (doi:10.1016/j.mce.2010.03.017)

Naing A, Kurzrock R, Burger A, Gupta S, Lei X, Busaidy N, Hong D, Chen HX, Doyle LA, Heilbrun LK, et al. 2011 Phase I trial of cixutumumab combined with temsirolimus in patients with advanced cancer. Clinical Cancer Research 17 6052-6060. (doi:10.1158/1078-0432.CCR-10-2979)

Naing A, Lorusso P, Fu S, Hong D, Chen HX, Doyle LA, Phan AT, Habra MA \& Kurzrock R 2013 Insulin growth factor receptor (IGF-1R) antibody cixutumumab combined with the mTOR inhibitor temsirolimus in patients with metastatic adrenocortical carcinoma. British Journal of Cancer 108 826-830. (doi:10.1038/bjc.2013.46)

Niemeijer ND, Alblas G, van Hulsteijn LT, Dekkers OM \& Corssmit EP 2014 Chemotherapy with cyclophosphamide, vincristine and dacarbazine for malignant paraganglioma and pheochromocytoma: systematic review and meta-analysis. Clinical Endocrinology 81 642-651. (doi:10.1111/cen.12542)

Nölting S \& Grossman AB 2012 Signaling pathways in pheochromocytomas and paragangliomas: prospects for future therapies. Endocrine Pathology 23 21-33. (doi:10.1007/s12022-012-9199-6)

Nölting S, Garcia E, Alusi G, Giubellino A, Pacak K, Korbonits M \& Grossman AB 2012 Combined blockade of signalling pathways shows marked anti-tumour potential in phaeochromocytoma cell lines. Journal of Molecular Endocrinology 49 79-96. (doi:10.1530/JME12-0028)

Nölting S, Giubellino A, Tayem Y, Young K, Lauseker M, Bullova P, Schovanek J, Anver M, Fliedner S, Korbonits M, et al. 2014 Combination of 13-Cis retinoic acid and lovastatin: marked antitumor potential in vivo in a pheochromocytoma allograft model in female athymic nude mice. Endocrinology 155 2377-2390. (doi:10.1530/jme-12-0028)

Oh DY, Kim TW, Park YS, Shin SJ, Shin SH, Song EK, Lee HJ, Lee KW \& Bang YJ 2012 Phase 2 study of everolimus monotherapy in patients with nonfunctioning neuroendocrine tumors or pheochromocytomas-paragangliomas. Cancer 118 6162-6170. (doi:10.1002/cncr.27675)

Olauson H, Lindberg K, Amin R, Sato T, Jia T, Goetz R, Mohammadi M, Andersson G, Lanske B \& Larsson TE 2013 Parathyroid-specific deletion of Klotho unravels a novel calcineurin-dependent FGF23 signaling pathway that regulates PTH secretion. PLoS Genetics 9 e1003975. (doi:10.1371/journal.pgen.1003975)

O’Reilly KE, Rojo F, She QB, Solit D, Mills GB, Smith D, Lane H, Hofmann F, Hicklin DJ, Ludwig DL, et al. 2006 mTOR inhibition induces upstream receptor tyrosine kinase signaling and activates 
Akt. Cancer Research 66 1500-1508. (doi:10.1158/0008-5472.CAN-052925)

Ortiz LD, Syro LV, Scheithauer BW, Ersen A, Uribe H, Fadul CE, Rotondo F, Horvath E \& Kovacs K 2012 Anti-VEGF therapy in pituitary carcinoma. Pituitary 15 445-449. (doi:10.1007/s11102011-0346-8)

O'Sullivan C, Edgerly M, Velarde M, Wilkerson J, Venkatesan AM, Pittaluga S, Yang SX, Nguyen D, Balasubramaniam S \& Fojo T 2014 The VEGF inhibitor axitinib has limited effectiveness as a therapy for adrenocortical cancer. Journal of Clinical Endocrinology and Metabolism 99 1291-1297. (doi:10.1210/jc.2013-2298)

Park SR, Speranza G, Piekarz R, Wright JJ, Kinders RJ, Wang L, Pfister T, Trepel JB, Lee MJ, Alarcon S, et al. 2013 A multi-histology trial of fostamatinib in patients with advanced colorectal, non-small cell lung, head and neck, thyroid, and renal cell carcinomas, and pheochromocytomas. Cancer Chemotherapy and Pharmacology $\mathbf{7 1}$ 981-90. (doi:10.1007/s00280-013-2091-3)

Pavel M, O'Toole D, Costa F, Capdevila J, Gross D, Kianmanesh R, Krenning E, Knigge U, Salazar R, Pape UF, et al. 2016 Vienna Consensus Conference participants. ENETS consensus guidelines update for the management of distant metastatic disease of intestinal, pancreatic, bronchial neuroendocrine neoplasms (NEN) and NEN of unknown primary site. Neuroendocrinology 103 172-185. (doi:10.1159/000443167)

Pollak M 2008 Insulin and insulin-like growth factor signaling in neoplasia. Nature Reviews Cancer 8 915-928. (doi:10.1038/nrc2536)

Puranik AD, Kulkarni HR, Singh A \& Baum RP 2015 Peptide receptor radionuclide therapy with $(90) \mathrm{Y} /(177) \mathrm{Lu}$-labelled peptides for inoperable head and neck paragangliomas (glomus tumours). European Journal of Nuclear Medicine and Molecular Imaging 42 1223-1230. (doi:10.1007/s00259-015-3029-2)

Quinkler M, Hahner S, Wortmann S, Johanssen S, Adam P, Ritter C, Strasburger C, Allolio B \& Fassnacht M 2008 Treatment of advanced adrenocortical carcinoma with erlotinib plus gemcitabine. Journal of Clinical Endocrinology and Metabolism 93 2057-2062. (doi:10.1210/ jc.2007-2564)

Raverot G, Sturm N, de Fraipont F, Muller M, Salenave S, Caron P, Chabre O, Chanson P, Cortet-Rudelli C, Assaker R, et al. 2010 Temozolomide treatment in aggressive pituitary tumors and pituitary carcinomas: a French multicenter experience. Journal of Clinical Endocrinology and Metabolism 95 4592-4599. (doi:10.1210/jc.2010-0644)

Raverot G, Castinetti F, Jouanneau E, Morange I, Figarella-Branger D, Dufour H, Trouillas J \& Brue T 2012 Pituitary carcinomas and aggressive pituitary tumours: merits and pitfalls of temozolomide treatment. Clinical Endocrinology 76 769-775. (doi:10.1111/j.1365-2265.2012.04381.x)

Reincke M, Sbiera S, Hayakawa A, Theodoropoulou M, Osswald A, Beuschlein F, Meitinger T, Mizuno-Yamasaki E, Kawaguchi K, Saeki Y, et al. 2015 Mutations in the deubiquitinase gene USP8 cause Cushing's disease. Nature Genetics 47 31-38. (doi:10.1038/ng.3166)

Ribeiro TC \& Latronico AC 2012 Insulin-like growth factor system on adrenocortical tumorigenesis. Molecular and Cellular Endocrinology 351 96-100. (doi:10.1016/j.mce.2011.09.042)

Saito H, Inagaki Y, Tsunenari T, Ura M, Mizuno H, Fujimoto-Ouchi K, Onuma E, Sato K, Ogata E \& Yamada-Okabe H 2007 Involvement of cyclooxygenase- 2 in the tumor site-dependent production of parathyroid hormone-related protein in colon 26 carcinoma. Cancer Science 98 1563-1569. (doi:10.1111/j.1349-7006.2007.00568.x)

Saito Y, Tanaka Y, Aita Y, Ishii KA, Ikeda T, Isobe K, Kawakami Y, Shimano H, Hara H \& Takekoshi K 2012 Sunitinib induces apoptosis in pheochromocytoma tumor cells by inhibiting VEGFR2/Akt/ mTOR/S6K1 pathways through modulation of Bcl-2 and BAD. American Journal of Physiology: Endocrinology and Metabolism 302 615-625. (doi:10.1152/ajpendo.00035.2011)

Sbiera S, Schmull S, Assie G, Voelker HU, Kraus L, Beyer M, Ragazzon B, Beuschlein F, Willenberg HS, Hahner S, et al. 2010 High diagnostic and prognostic value of steroidogenic factor-1 expression in adrenal tumors. Journal of Clinical Endocrinology and Metabolism 95 161-171. (doi:10.1210/jc.2010-0653)

Schneider MR, Sibilia M \& Erben RG 2009 The EGFR network in bone biology and pathology. Trends in Endocrinology and Metabolism 20 517e524 (doi:10.1016/j.tem.2009.06.008)

Semenza GL 2007 Evaluation of HIF-1 inhibitors as anticancer agents. Drug Discovery Today 20 853-859. (doi:10.1016/j.drudis.2007.08.006)

Strosberg J, El-Haddad G, Wolin E, Hendifar A, Yao J, Chasen B, Mittra E, Kunz PL, Kulke MH, Jacene H, et al. 2017 NETTER-1 trial investigators. Phase 3 trial of (177)Lu-Dotatate for midgut neuroendocrine tumors. New England Journal of Medicine 376 125-135. (doi:10.1056/NEJMoa1607427)

Subramanian C, Kuai R, Zhu Q, White P, Moon JJ, Schwendeman A \& Cohen MS 2016 Synthetic high-density lipoprotein nanoparticles: a novel therapeutic strategy for adrenocortical carcinomas. Surgery 159 284-295. (doi:10.1016/j.surg.2015.08.023)

Suh I, Weng J, Fernandez-Ranvier G, Shen WT, Duh QY, Clark OH \& Kebebew E 2010 Antineoplastic effects of decitabine, an inhibitor of DNA promoter methylation, in adrenocortical carcinoma cells. Archives of Surgery 145 226-232. (doi:10.1001/archsurg.2009.292)

Sze WC, Grossman AB, Goddard I, Amendra D, Shieh SC, Plowman PN, Drake WM, Akker SA \& Druce MR 2013 Sequelae and survivorship in patients treated with ${ }^{131} \mathrm{I}-\mathrm{MIBG}$ therapy. British Journal of Cancer 109 565-572. (doi:10.1038/bjc.2013.365)

Takekoshi K, Isobe K, Yashiro T, Hara H, Ishii K, Kawakami Y, Nakai T \& Okuda Y 2004 Expression of vascular endothelial growth factor (VEGF) and its cognate receptors in human pheochromocytomas. Life Science 74 863-871. (doi:10.1016/j.lfs.2003.07.036)

Tavangar SM, Shojaee A, Moradi Tabriz H, Haghpanah V, Larijani B, Heshmat R, Lashkari A \& Azimi S 2010 Immunohistochemical expression of Ki67, c-erbB-2, and c-kit antigens in benign and malignant pheochromocytoma. Pathology-Research Practice 206 305-309. (doi:10.1016/j.prp.2010.01.007)

Terzolo M, Angeli A, Fassnacht M, Daffara F, Tauchmanova L, Conton PA, Rossetto R, Buci L, Sperone P \& Grossrubatscher E 2007 Adjuvant mitotane treatment for adrenocortical carcinoma. New England Journal of Medicine 356 2372-2380 (doi:10.1056/NEJMoa063360)

Thearle MS, Freda PU, Bruce JN, Isaacson SR, Lee Y \& Fine RL 2011 Temozolomide (Temodar(R)) and capecitabine (Xeloda(R)) treatment of an aggressive corticotroph pituitary tumor. Pituitary 14 418-424. (doi:10.1007/s11102-009-0211-1)

Tissier F, Cavard C, Groussin L, Perlemoine K, Fumey G, Hagneré AM, René-Corail F, Jullian E, Gicquel C, Bertagna X, et al. 2005 Mutations of beta-catenin in adrenocortical tumors: activation of the Wnt signaling pathway is a frequent event in both benign and malignant adrenocortical tumors. Cancer Research 65 7622-7627.

Urakawa I, Yamazaki Y, Shimada T, Iijima K, Hasegawa H, Okawa K, Fujita T, Fukumoto S \& Yamashita T 2006 Klotho converts canonical FGF receptor into a specific receptor for FGF23. Nature 444 770-774. (doi:10.1038/nature05315)

van der Lely AJ, Biller BM, Brue T, Buchfelder M, Ghigo E, Gomez R, Hey-Hadavi J, Lundgren F, Rajicic N, Strasburger CJ, et al. 2012 Longterm safety of pegvisomant in patients with acromegaly: comprehensive review of 1288 subjects in ACROSTUDY. Journal of Clinical Endocrinology and Metabolism 97 1589-1597. (doi:10.1210/jc.2011-2508)

Val P, Lefrancois-Martinez AM, Veyssiere G \& Martinez A 2003 SF-1 a key player in the development and differentiation of steroidogenic tissues. Nuclear Receptor 1 8. (doi:10.1186/1478-1336-1-8)

van Essen M, Krenning EP, Kooij PP, Bakker WH, Feelders RA, de Herder WW, Wolbers JG, Kwekkeboom DJ, et al. 2006 Effects of therapy with [177Lu-DOTA0, Tyr3] octreotate in patients with paraganglioma, meningioma, small cell lung carcinoma, and melanoma. Journal of Nuclear Medicine 47 1599-1606.

Van Hulsteijn LT, van Duinen N, Verbist BM, Jansen JC, van der Klaauw AA, Smit JW \& Corssmit EP 2013 Effects of octreotide therapy in progressive head and neck paragangliomas: case series. Head Neck $\mathbf{3 5}$ 391-396. (doi:10.1002/hed.23348) 
van Hulsteijn LT, Niemeijer ND, Dekkers OM \& Corssmit EP 2014 (131) IMIBG therapy for malignant paraganglioma and phaeochromocytoma: systematic review and meta-analysis. Clinical Endocrinology 80 487-501. (doi:10.1111/cen.12341)

van Koetsveld PM, Vitale G, Feelders RA, Waaijers M, Sprij-Mooij DM, de Krijger RR, Speel EJM, Hofland J, Lamberts SWJ, de Herder WW, et al. 2013 Interferon-beta is a potent inhibitor of cell growth and cortisol production in vitro and sensitizes human adrenocortical carcinoma cells to mitotane. Endocrine-Related Cancer 20 443-454. (doi:10.1530/ERC-12-0217)

Van Noort M, Meeldijk J, van der Zee R, Destree O \& Clevers H 2002 Wnt signaling controls the phosphorylation status of beta-catenin. Journal of Biological Chemistry 277 17901-17905. (doi:10.1074/jbc. M111635200)

Veytsman I, Nieman L \& Fojo T 2009 Management of endocrine manifestations and the use of mitotane as a chemotherapeutic agent for adrenocortical carcinoma. Journal of Clinical Oncology 27 4619-4629. (doi:10.1200/JCO.2008.17.2775)

Vitagliano D, De Falco V, Tamburrino A, Coluzzi S, Troncone G, Chiappetta G, Ciardiello F, Tortora G, Fagin JA, Ryan AJ, et al. 2011 The tyrosine kinase inhibitor ZD6474 blocks proliferation of RET mutant medullary thyroid carcinoma cells. Endocrine-Related Cancer 18 1-11. (doi:10.1677/ERC-09-0292)

Vlotides G, Siegel E, Donangelo I, Gutman S, Ren SG \& Melmed S 2008 Rat prolactinoma cell growth regulation by epidermal growth factor receptor ligands. Cancer Research 68 6377-6386. (doi:10.1158/00085472.CAN-08-0508)

Waligórska-Stachura J, Gut P, Sawicka-Gutaj N, Liebert W, Gryczyńska M, Baszko-Błaszyk D, Blanco-Gangoo AR \& Ruchała M 2016 Growth hormone-secreting macroadenoma of the pituitary gland successfully treated with the radiolabeled somatostatin analog (90)Y-DOTATATE: case report. Journal of Neurosurgery 125 346-349. (doi:10.3171/2015. 6.jns15363)

Wang CP, Zhang J, Gao J, Liu PP, Wu SF, Zeng X \& Liang ZY 2012 Clinicopathologic features and expression of epidermal growth factor receptor and vascular endothelial growth factor in adrenocortical tumors. Zhonghua Bing Li Xue Za Zhi 41 686-690.

Wei CH \& Harari A 2012 Parathyroid carcinoma: update and guidelines for management. Current Treatment Options in Oncology 13 11-23. (doi:10.1007/s11864-011-0171-3)

West AN, Neale GA, Pounds S, Figueredo BC, Rodriguez Galindo C, Pianovski MA, Oliveira Filho AG, Malkin D, Lalli E \& Ribeiro R 2007 Gene expression profiling of childhood adrenocortical tumors. Cancer Research 67 600-608. (doi:10.1158/0008-5472.CAN-06-3767)

Wilhelm SM, Wang TS, Ruan DT, Lee JA, Asa SL, Duh QY, Doherty GM, Herrera MF, Pasieka JL, Perrier ND, et al. 2016 The American association of endocrine surgeons guidelines for definitive management of primary hyperparathyroidism. JAMA Surgery $\mathbf{1 5 1}$ 959-968. (doi:10.1001/jamasurg.2016.2310)

Wortmann S, Quinkler M, Ritter C, Kroiss M, Johanssen S, Hahner S, Allolio B, Fassnacht M, et al. 2010 Bevacizumab plus capecitabine as a salvage therapy in advanced adrenocortical carcinoma. European Journal of Endocrinology 162 349-356. (doi:10.1530/EJE-09-0804)

Xu YZ, Zhu Y, Shen ZJ, Sheng JY, He HC, Ma G, Qi YC, Zhao JP, Wu YX, Rui WB, et al. 2011 Significance of heparanase-1 and vascular endothelial growth factor in adrenocortical carcinoma angiogenesis: potential for therapy. Endocrine 40 445-451. (doi:10.1007/s12020011-9502-1)

Xu L, Qi Y, Xu Y, Lian J, Wang X, Ning G, Wang W \& Zhu Y 2016 Co-inhibition of EGFR and IGF1R synergistically impacts therapeutically on adrenocortical carcinoma. Oncotarget 7 36235-36246. (doi:10.18632/oncotarget.8827)

Yang C, Zhuang Z, Fliedner SM, Shankavaram U, Sun MG, Bullova P, Zhu R, Elkahloun AG, Kourlas PJ, Merino M, et al. 2015 Germ-line PHD1 and PHD2 mutations detected in patients with pheochromocytoma/paraganglioma-polycythemia. Journal of Molecular Medicine 93 93-104. (doi:10.1007/s00109-014-1205-7)

Yavropoulou MP, Maladaki A \& Yovos JG 2015 The role of Notch and Hedgehog signaling pathways in pituitary development and pathogenesis of pituitary adenomas. Hormones 14 5-18.

Yeh MW, Ituarte PH, Zhou HC, Nishimoto S, Liu IL, Harari A, Haigh PI \& Adams AL 2013 Incidence and prevalence of primary hyperparathyroidism in a racially mixed population. Journal of Clinical Endocrinology and Metabolism 98 1122-1129. (doi:10.1210/ jc.2012-4022)

Yoshinaga K, Oriuchi N, Wakabayashi H, Tomiyama Y, Jinguji M, Higuchi T, et al. 2014 Effects and safety of (131) imetaiodobenzylguanidine (MIBG)-radiotherapy in malignant neuroendocrine tumors: results from a multicenter observational registry. Endocrine Journal 61 1171-1180. (doi:10.1507/endocrj.EJ14-0211)

Zada G, Woodmansee WW, Ramkissoon S, Amadio J, Nose V \& Laws ER Jr 2011 Atypical pituitary adenomas: incidence, clinical characteristics, and implications. Journal of Neurosurgery 114 336-344 (doi:10.3171/2010.8.JNS10290)

Zatelli MC, Minoia M, Filieri C, Tagliati F, Buratto M, Ambrosio MR, Lapparelli M, Scanarini M \& Degli Uberti EC 2010 Effect of everolimus on cell viability in nonfunctioning pituitary adenomas. Journal of Clinical Endocrinology and Metabolism 95 968-976. (doi:10.1210/jc 2009-1641)

Zeiger MA, Thompson GB, Duh QY, Hamrahian AH, Angelos P, Elaraj D, Fishman E \& Kharlip J 2009 American association of clinical endocrinologists. American association of endocrine surgeons. American association of clinical endocrinologists and American association of endocrine surgeons medical guidelines for the management of adrenal incidentalomas: executive summary of recommendations. Endocrine Practice 15 450-453. (doi:10.4158/ EP.15.5.450)

Zhang X, Wang X, Xu T, Zhong S \& Shen Z 2015 Targeting of mTORC2 may have advantages over selective targeting of MTORC1 in the treatment of malignant pheochromocytoma. Tumour Biology $\mathbf{3 6}$ 5273-5281. (doi:10.1007/s13277-015-3187-7)

Ziegler CG, Brown JW, Schally AV, Erler A, Gebauer L, Treszl A, Young L, Fishman LM, Engel JB, Willenberg HS, et al. 2009 Expression of neuropeptide hormone receptors in human adrenal tumors and cell lines: antiproliferative effects of peptide analogues. PNAS 106 15879-15884. (doi:10.1073/pnas.0907843106)

Zielke A, Middeke M, Hoffmann S, Colombo-Benkmann M, Barth P, Hassan I, Wunderlich A, Hofbauer LC \& Duh QY 2002 VEGFmediated angiogenesis of human pheochromocytomas is associated to malignancy and inhibited by anti-VEGF antibodies in experimental tumors. Surgery 132 1056-1063. (doi:10.1067/ msy.2002.128613)

Zografos GN, Vasiliadis G, Farfaras AN, Aggeli C \& Digalakis M 2009 Laparoscopic surgery for malignant adrenal tumors. Journal of the Society of Laparoendoscopic Surgeons 13 196-202.

Zovato S, Kumanova A, Demattè S, Sansovini M, Bodei L, Di Sarra D, Casagranda E, Severi S, Ambrosetti A, Schiavi F, et al. 2012 Peptide eceptor radionuclide therapy (PRRT) with 177Lu-DOTATATE in individuals with neck or mediastinal paraganglioma (PGL). Hormone and Metabolic Research 44 411-414. (doi:10.1055/s-0032-1311637)

Received in final form 20 March 2017

Accepted 10 April 2017

Accepted Preprint published online 11 April 2017 http://erc.endocrinology-journals.org DOI: 10.1530/ERC-16-0542
๑ 2017 Society for Endocrinology Printed in Great Britain
Published by Bioscientifica Ltd. 